NBER WORKING PAPER SERIES

\title{
WHAT MATTERS FOR ELECTRIFICATION? EVIDENCE FROM 70 YEARS OF U.S. HOME HEATING CHOICES
}

\author{
Lucas W. Davis \\ Working Paper 28324 \\ http://www.nber.org/papers/w28324 \\ NATIONAL BUREAU OF ECONOMIC RESEARCH \\ 1050 Massachusetts Avenue \\ Cambridge, MA 02138 \\ January 2021
}

I am grateful to seminar participants at UC Berkeley and the University of Wisconsin for helpful comments and to Pengyu Wang for excellent research assistance. I have not received any financial compensation for this project nor do I have any financial relationships that relate to this research. The analysis relies entirely on publicly-available data and all data and code will be posted on my website upon completion of the project. The views expressed herein are those of the author and do not necessarily reflect the views of the National Bureau of Economic Research.

NBER working papers are circulated for discussion and comment purposes. They have not been peer-reviewed or been subject to the review by the NBER Board of Directors that accompanies official NBER publications.

(C) 2021 by Lucas W. Davis. All rights reserved. Short sections of text, not to exceed two paragraphs, may be quoted without explicit permission provided that full credit, including ( $)$ notice, is given to the source. 
What Matters for Electrification? Evidence from 70 Years of U.S. Home Heating Choices

Lucas W. Davis

NBER Working Paper No. 28324

January 2021

JEL No. H23,L51,Q41,Q42,Q48,Q54

\begin{abstract}
$\underline{\text { ABSTRACT }}$
The percentage of U.S. homes heated with electricity has increased steadily from $1 \%$ in 1950 , to $8 \%$ in 1970 , to $26 \%$ in 1990 , to $39 \%$ in 2018 . This paper investigates the key determinants of this increase in electrification using data on heating choices from millions of U.S. households over a 70-year period. Energy prices, geography, climate, housing characteristics, and household income are shown to collectively explain $90 \%$ of the increase, with changing energy prices by far the most important single factor. This framework is then used to calculate the economic cost of an electrification mandate for new homes. Households in warm states are close to indifferent between electric and natural gas heating, so would be made worse off by less than $\$ 500$ annually. Household in cold states, however, tend to strongly prefer natural gas so would be made worse off by $\$ 3000+$ annually. These findings are directly relevant to a growing number of policies aimed at reducing carbon dioxide emissions through electrification, and underscore the importance of pricing energy efficiently.
\end{abstract}

Lucas W. Davis

Haas School of Business

University of California

Berkeley, CA 94720-1900

and NBER

ldavis@haas.berkeley.edu 


\section{Introduction}

U.S. households burn vast amounts of fossil fuels on-site for space heating: 2.7 trillion cubic feet of natural gas, 2.9 billion gallons of heating oil, and 2.5 billion gallons of propane annually. ${ }^{1}$ This fossil fuel consumption is the carbon dioxide equivalent of having 40 million cars on the road. ${ }^{2}$ Burning fossil fuels also contributes to local particulate pollution and ozone, as well as to upstream externalities including water contamination and methane leakage. ${ }^{3}$

Policymakers are increasingly turning to electrification in an effort to reduce these externalities. The "electrify everything" movement recently gained attention when Berkeley CA, became the first city in the United States to ban natural gas on all new residential construction. ${ }^{4}$ More than thirty cities in California have now enacted measures limiting or prohibiting natural gas in new homes, and cities in Washington, New York, Massachusetts, and Rhode Island have introduced "electric-preferred" building codes. ${ }^{5}$

Proponents argue that electrification is critical if the United States is to sharply re-

\footnotetext{
${ }^{1}$ U.S. Department of Energy, Energy Information Administration, "Energy Consumption and Expenditure Tables from Residential Energy Consumption Survey", "Table CE4.1 Annual Household Site End-Use Consumption by Fuel in the U.S.- Totals", released May 2018.

${ }^{2}$ U.S. Department of Energy, Energy Information Administration, "Carbon Dioxide Emissions Coefficients" and U.S. Department of Transportation, "Highway Statistics", "Annual Vehicle Distance Traveled in Miles and Related Data by Highway Category and Vehicle Type, Table VM-1.

${ }^{3}$ For water contamination impacts see, e.g. Olmstead et al. (2013) and Llewellyn et al. (2015). For methane leakage see, e.g, McKain et al. (2015) and Alvarez et al. (2018).

${ }^{4}$ See, e.g., "All-Electric Movement Picks Up Speed, Catching Some Off Guard," New York Times, Jane Morgolies, February 4, 2020.

5 "To Cut Carbon Emissions, a Movement Grows to "Electrify Everything"', PBS News Hour, April 17, 2020. "Banning Natural Gas is Out; Electrifying Buildings Is In", SËP Global, Tom DiChristopher, July 8, 2020.
} 
duce carbon dioxide emissions from the building sector. ${ }^{6}$ The U.S. electricity sector has become much less carbon-intensive, making this a more viable path to decarbonization than even just a few years ago (Holland et al., 2016, 2020). Critics argue that electric heating costs more than natural gas per unit of heating, so electrification mandates can be expensive and regressive. ${ }^{7}$

Mostly missing from this discussion, however, is that home electrification is nothing new. As this paper documents, the percentage of U.S. homes heated with electricity has increased steadily from $1 \%$ in 1950 , to $8 \%$ in 1970 , to $26 \%$ in 1990 , to $39 \%$ in 2018. This paper uses data on heating choices from millions of U.S. households over a 70-year period to investigate the key determinants of this increase. The paper proposes five hypotheses, collects data on all five, and then designs an empirical framework aimed at testing and quantifying each factor.

Overall, the five factors are shown to explain $90 \%+$ of the increase in electrification since 1950. By far, the single most important single factor is energy prices. Average U.S. residential electricity prices have fallen 58\% in real terms since 1950, while average residential prices for natural gas and heating oil have increased $27 \%$

\footnotetext{
${ }^{6} \mathrm{~A}$ recent study commissioned by the California Energy Commission concluded that, "building electrification is likely to be a lower-cost, lower-risk long-term strategy compared to renewable natural gas [e.g. hydrogen]. Furthermore, electrification across all sectors, including in buildings, leads to significant improvements in outdoor air quality and public health." (Aas et al., 2020). A report commissioned for the California Air Resources Board includes building electrification among the "least-regrets" approaches for the state to reach carbon neutrality by 2045, with a "significant reduction" in residential consumption of natural gas in all scenarios (Mahone et al., 2020). An earlier report by a sustainability-oriented research and consulting organization found that electrification of space heating "presents a viable pathway to deep decarbonization" (Billimoria et al., 2018).

7 "Should Cities Phase Out Gas Appliances and Require New Buildings to Be All Electric?" Wall Street Journal, November 19, 2019. "Natural Gas Bans Will Worsen California's Poverty Problem" Real Clear Energy, Robert Bryce, August 9, 2020.
} 
and $79 \%$, respectively. Heating choices are shown to be highly sensitive to energy prices such that the change in energy prices can explain $70 \%+$ of the increase in electrification.

Geography and climate matter too. Electric heating has lower initial capital costs than other forms of heating, so is preferred by households in warmer climates. Over this 70-year period there has been a pronounced shift in new housing construction toward warmer states, and this changing geography can explain $11 \%$ of the increase in electrification. In addition, climate change is making all parts of the United States more conducive to electric heating, and this factor can explain $4 \%$ of the increase in electrification.

Other factors have only a modest impact. Multi-unit homes are more likely to use electric heating, so the increased prevalence of multi-unit homes since 1950 can explain $4 \%$ of the increase in electrification. Other housing characteristics like the number of bedrooms end up less quantitatively important. Finally, higher income households are found to be slightly less likely to choose electric heating, but the effect is so small in magnitude that rising incomes since 1950 have essentially zero effect on electrification.

These data and framework are then used to calculate the economic cost of an electrification mandate for new homes. A discrete choice model is used to calculate the compensating variation, i.e. how much income households would need to receive to make them indifferent between the current environment in which they can choose any heating choice they would like, and an electrification mandate. Households in warm 
states are close to indifferent between electric and natural gas heating, so would be made worse off by less than $\$ 500$ annually. Household in cold states, however, tend to strongly prefer natural gas so would be made worse off by $\$ 3000+$ annually.

There are very few existing economic analyses of electrification. I am not aware of any previous study documenting or attempting to understand this 70 -year increase in U.S. home electrification, nor am I aware of any studies calculating the economic cost of an electrification mandate. Most previous economic analyses of home heating were written well before this recent policy interest in electrification, and with quite different research objectives (Dubin and McFadden, 1984; Dubin, 1985; Mansur et al., 2008; Davis and Kilian, 2011).

Although there has been little economic analysis of electrification, there are parallels which can be drawn from recent studies of energy-efficiency. See, e.g. Allcott and Greenstone (2012), Gillingham and Palmer (2014) and Gerarden et al. (2017) and references therein. With both electrification and energy-efficiency, supporters advocate for particular investments in order to reduce carbon dioxide emissions and other externalities from fossil fuels, and research is needed to quantify the cost-effectiveness of these investments.

The paper proceeds as follows. Section 2 describes the data and presents descriptive statistics on U.S. heating choices, energy prices, new home construction, and climate. Section 3 presents regression estimates on the determinants of electric heating and then performs a decomposition analysis, calculating how much of the increase in electrification can be explained by various factors. Section 4 introduces the discrete 
choice model and then estimates reservation prices, heating demand, and compensating variation. Section 5 concludes.

\section{Data}

\subsection{Heating Choices}

The core dataset for this analysis was compiled using five waves of the U.S. Census: 1960, 1970, 1980, 1990, and 2000, along with ten waves of the U.S. American Community Survey: 2000, 2002, 2004, 2006, 2008, 2010, 2012, 2014, 2016, and 2018. All of these surveys ask respondents about their primary form of home heating. The key question asks "Which fuel is used most for heating this house?". These data also provide information on the age of the home, household income, housing characteristics, and the state of residence. Census and ACS sampling weights are used throughout the analysis. See Ruggles et al. (2020) for details.

Figure 1 shows the growth in electric heating 1950-2018. Only 1\% of U.S. households in 1950 used electricity as their primary heating fuel. ${ }^{9}$ By 1960, this had increased to $2 \%$, led by Washington, Oregon, Nevada, and Tennessee, four states that had access to cheap Federal electricity via the Bonneville Power Administration and the Tennessee Valley Authority. By 1970, 8\% of U.S. households used electricity as their

\footnotetext{
${ }^{8}$ The home heating question is not asked to respondents in group quarters (e.g. correctional facilities, nursing homes, college dormitories) so these individuals are excluded from all analyses.

${ }^{9}$ The 1950 map is constructed somewhat differently from the map for subsequent years. The home heating question was introduced with the 1960 Census. Therefore, the 1950 map was constructed using homes in the 1960 census which were at least ten years old. This is a bit less accurate as it misses homes that were retrofitted with a new form of primary heating between 1950 and 1960.
} 
primary form of heating. Electric heating became more common in southern states like Mississippi, Alabama, Georgia, and North Carolina, as well as in Western states like Nevada, Arizona, Idaho, and Oregon.

Electric heating reached $18 \%$ in $1980,26 \%$ in $1990,30 \%$ in $2000,35 \%$ in 2010 , and $39 \%$ in 2018. There is a clear geographic pattern. Perhaps most strikingly, the maps show how electricity has grown to become the dominant form of heating in the Southeast, $50 \%+$ throughout the region and 90\%+ in Florida. Electric heating is also prevalent throughout the West and Midwest, particularly in the Pacific Northwest where rich hydroelectric resources contribute to lower than average residential electricity prices.

These heating choices have significant implications for energy consumption and carbon dioxide. The United States is a relatively cold country, so heating is by far the most important component of total household energy consumption. Adding up across all fuel types, U.S. households use annually an estimated 3.9 quadrillion Btus for space heating, compared to 1.7 quadrillion Btus for water heating, 0.7 quadrillion Btus for air conditioning, and 0.3 quadrillion Btus for refrigerators. ${ }^{10}$ Overall, space heating is responsible for $43 \%$ of U.S. household energy consumption. ${ }^{11}$

\footnotetext{
${ }^{10}$ U.S. Department of Energy, Energy Information Administration, "Energy Consumption and Expenditure Tables from Residential Energy Consumption Survey", "Table CE2.1 Annual Household Site End-Use Consumption in the U.S.-Totals", released May 2018.

${ }^{11}$ Ibid.
} 


\subsection{Energy Prices}

Residential prices for electricity, natural gas, and heating oil by state and year were compiled from various sources. Prices from 1950-1969 come from Edison Electric Institute (1950-1969), American Gas Association (1950-1969), and Platts Oil (19501969). Data from after 1970 come from U.S. Department of Energy, Energy Information Administration (1970-2018). Prices are average annual revenue from residential sales. Utilities and other retailers report energy sales and revenue by customer class, and average residential prices are calculated by dividing total residential revenue by total residential sales. Prices include all relevant taxes and, where appropriate, delivery charges. All prices throughout the paper have been normalized to reflect year 2020 dollars.

Figure 2 plots residential energy prices by state. Data series are labeled for the four most populous U.S. states. As mentioned earlier, average residential electricity prices have fallen $58 \%$ in real terms since 1950, while average residential prices for natural gas and heating oil have increased $27 \%$ and $79 \%$, respectively.

There is considerable variation in electricity and natural gas prices, both over time and across states. For heating oil, there is considerable variation over time, but little variation across states. See Appendix Figure 1 for maps of residential average energy prices as of 2018. The model is identified using both forms of variation. Results are reported from specifications with and without region- and division- fixed effects and with and without year fixed effects to assess how parameter estimates differ using alternative sources of identifying variation. 
Potential price endogeneity is mitigated in this context. Residential energy prices tend to be driven by supply-side factors, for example, natural advantages in hydroelectric and other forms of electricity generation, natural gas price regulation and deregulation, and technological advances in oil and natural gas production like hydraulic fracturing. In addition, to the extent there are demand shocks to heating system choices, only a small fraction of households make a heating system choice in a given year, so such shocks would be unlikely to meaningfully impact total energy demand or market prices. It is worth highlighting also that both electricity and natural gas are delivered by regulated utilities so prices are determined using rate-of-return regulation.

\subsection{Heating Degree Days}

Heating degree days (HDDs) by state and year since 1950 come from NOAA (2020). HDDs are often used as a summary measure for heating demand as they reflect both the number of cold days as well as the intensity of cold on those days. ${ }^{12}$ The HDDs from NOAA are population weighted to reflect the within-state distribution of where people live, and adjusted to account for artificial effects introduced into the climate record by instrument changes, station relocation, and other factors.

Heating system choices are made based on expected long-run climatological conditions, not year-to-year variation in HDDs. Therefore, rather than use these raw data, the analyses which follow use fitted values from a linear time trend estimated

\footnotetext{
${ }^{12} \mathrm{HDDs}$ are calculated as the sum of daily mean temperatures in Fahrenheit below $65^{\circ} \mathrm{F}$. For example, a day with an average temperature of $55^{\circ} \mathrm{F}$ has ten HDDs, whereas a day with an average temperature of $75^{\circ} \mathrm{F}$ has zero HDDs.
} 
separately by state. Figure 3 describes the change in annual HDDs between 1950 and 2019. On average, HDDs decreased by 10\% between 1950 and 2019. In absolute terms the HDD decreases are larger in the North. For example, Minnesota had 9,300 HDDs in 1950 and 8,400 HDDs in 2019, for a decrease of 900 HDDs. Florida, in contrast, had 800 HDDs in 1950 and 600 HDDs in 2019, for a decrease of 200 HDDs. See Appendix Figure 2 for maps showing average HDDs by decade.

\subsection{Estimation Sample}

The merged dataset is restructured to describe heating system choices at the time each home was constructed. The rationale for the focus on relatively new homes is that there is considerable inertia in these heating system choices. When a new home is built, a choice must be made as to whether the home is heated with electricity or some other heating fuel. Later on a home can be retrofitted, for example, from heating oil to natural gas, but the timing of these retrofits is less clear and not observed in our data. Most of the policy interventions currently being discussed are primarily focused at new homes, providing further motivation for the focus on choices at the time of construction.

In particular, the sample is restricted to homes built in the last 10 years as of the time of each survey. For example, from the 1960 Census, the sample is restricted to homes built during the 1950s. While the 1970 Census and later Censuses also includes homes built in the 1950s, these observations are excluded because these homes are more likely to have been retrofitted. Focusing on these initial heating system choices makes it possible to to confidently match each observation to energy 
prices, climate, and other factors at the time the choice was made.

Recent waves of the ACS provide the exact age for newer homes. However, a limitation of the early waves of the ACS and all waves of the census is that they instead provide a discrete range for age. For homes built in the last 10 years, there are typically three categories: 0-1 year, 2-5 years, and 6-10 years. These homes are assigned to specific construction years based approximately on the midpoint of each age range. Specifically, homes 0-1 years old are assumed to be 1 year old, homes 2-5 years old are assumed to be 4 years old, and homes 6-10 years old are assumed to be 8 years old. This assignment matters because it determines the energy prices and heating degree days to which each observation is matched. For a given state, energy prices and heating degree days change slowly year-to-year, however, so this imperfect assignment introduces only a small amount of measurement error.

\subsection{Descriptive Statistics}

Table 1 reports descriptive statistics. The estimation sample includes 4.2 million total observations. Panel $(\mathrm{A})$ describes the dramatic increase in electric heating over this time period. The overall pattern is similar to Figure 1, though the table describes the "flow" (i.e. new homes built in each decade) rather than the "stock" (i.e. all homes as of a particular year). The percentage of new homes heated with electricity increases from $4 \%$ during the 1950 s to $53 \%$ during the 2010 s.

Panels (B) and (C) show residential energy prices and HDDs. Changes over time in these averages reflect both time-series variation and changes in where new homes 
are being constructed. For example, HDDs in Panel (C) decrease more rapidly than in Figure 3 because they reflect climate change as well as a relative increase in new home construction in warmer states. See Panel (D). Finally, Panel (E) shows changes in household demographics and housing characteristics. Perhaps most notably this shows the large increase in average household income since the 1950s.

All five hypotheses are at least partly visible in Table 1: (1) changing energy prices, (2) increased home construction in warmer states, (3) climate change, (4) changing housing characteristics, and (5) rising household incomes. What descriptive statistics cannot reveal however, is the relative contribution of these different factors to U.S. home electrification. The following section therefore turns to regression and decomposition analyses to quantify the relative magnitudes.

\section{The Determinants of Electric Heating}

\subsection{Energy Prices}

Table 2 reports coefficient estimates and standard errors from six separate least squares regressions. In all six regressions the dependent variable is an indicator variable for homes for which electricity is the primary form of heating. Later in the paper, Section 4 introduces a discrete choice model, but for these regression and decomposition analyses, the linear probability model is preferred because it is particularly easy-to-interpret and makes fewer assumptions. Estimates are reported for specifications with and without year fixed effects, and with and without region-, and division- fixed effects. 
The most striking feature of Table 2 is the pronounced negative relationship between electricity prices and electrification. In column (6), for example, a $10 \%$ increase in electricity prices decreases electric heating by 4.2 percentage points. This is a large effect. In 2018, residential electricity prices ranged from 9.6 cents in Louisiana to 21.6 cents in Massachusetts, a difference of $0.81 \log$ points. The model implies that, ceteris paribus, an increase in electricity prices of this magnitude would decrease electric heating by 32 percentage points. ${ }^{13}$ The estimated coefficients on electricity prices are similar across columns and statistically significant at the $1 \%$ level throughout.

Natural gas and heating oil prices matter too. These cross-price effects are expected to be positive and the point estimates are indeed positive in most cases. In column (6), for example, $10 \%$ increases in natural gas and heating oil prices increase electric heating by 2.1 and 0.6 percentage points, respectively. The estimated coefficients on natural gas prices are consistently positive and statistically significant at the $1 \%$ level, ranging from 0.15 to 0.29 . The estimated coefficients on heating oil prices are smaller in magnitude and mostly not statistically significant.

These regressions are a reduced-form characterization of an intertemporal decision in which households are making a tradeoff between capital and operating costs. Economists have long pointed out that demand for energy is derived from demand for household services (Hausman, 1979; Dubin and McFadden, 1984) with technology

\footnotetext{
${ }^{13}$ In related work, several previous studies estimate the short-run price elasticity of demand for electricity. See, e.g., Reiss and White (2005), Reiss and White (2008) and Ito (2014). The shortrun price elasticity of demand primarily reflects changes in the intensity of usage, not changes in technology. Other studies have looked explicitly at technology changes. For example, Sahari (2019) finds that when electricity prices rose in Finland 2006-2011, households substituted away from electric heating and toward wood heating and ground source heat pumps.
} 
choices and demand for energy determined jointly as the solution to a household production problem (Davis, 2008; Rapson, 2014). ${ }^{14}$ No utility is derived from a heating system itself, but households value thermal comfort which is produced in part with a heating system.

This specification assumes that what matters for heating system choices is current energy prices. This assumption is natural when energy prices are well approximated by a random walk and changes in energy prices are unpredictable. This is a reasonable assumption in many contexts (Anderson et al., 2013), although a case could be made that the steady decreases in real electricity prices during the 1950s and 1960s could have been anticipated by some households. Although the specifications in Table 2 do not incorporate such expectations, it is worth noting that the estimates are similar with- and without year fixed effects, implying that the estimates are not unduly sensitive to controls for this year-to-year pattern.

\subsection{Other Covariates}

There are several other notable estimates in Table 2. First, income has only a very small impact on adoption of electric heating. Higher income households are slightly less likely to choose electric heating. Across all eight specifications the point estimate is negative and statistically significant, but in all cases very small in magnitude.

\footnotetext{
${ }^{14}$ A question which arises in this context is whether households are "myopic" when they make technology investments. Early work by Hausman (1979) and Dubin and McFadden (1984) found heating and cooling choices consistent with high implied discount rates, perhaps indicating information problems or other market failures, but more recent work has tended to find lower discount rates (Myers, 2019). There is also an analogous literature on automobile purchases (see, e.g. Busse et al., 2013; Allcott and Wozny, 2014).
} 
For example, in column (6) the exact point estimate is -0.0002 , indicating that an additional $\$ 100,000$ in annual household income decreases electric heating by only 2 percentage points.

The negative coefficient on income is a bit surprising. Electric heating is cleaner than other forms of heating, with no on-site combustion or on-site emissions. Also with electric heating there is no furnace repair, no storage tank, and no need to schedule fuel deliveries as one must do with heating oil. But regardless of the exact explanation, this lack of sensitivity to income implies that income growth over this time period is unlikely to explain more than a very small amount of the increase in electrification. Higher-income households appear to view these tradeoffs with electric heating approximately in the same way as lower-income households.

Second, heating degree days have a strong negative effect. In column (6) an additional 1000 HDDs decreases electric heating by 6 percentage points. This is a large effect. For example, current HDDs in Minnesota and Florida are 8,400 and 600, respectively. Thus the coefficient on HDDs imply that, everything else equal, households in Minnesota are 47 percentage points less likely to choose electric heating than households in Florida. Households in cold climates tend not to choose electricity because of the high price per unit of heating.

Third, housing characteristics matter. Homes with 4- and 5- bedrooms are considerably less likely to be electric - whereas mobile homes, attached homes, and, multi-unit homes are more likely to be electric. This pattern makes sense because of economies-of-scale in forced air heating. Many new multi-unit buildings use elec- 
tricity because it less capital-intensive and because shared walls imply lower overall heating demand.

Finally, rented homes are more likely to have electric heat. This is consistent with the "landlord-tenant problem". See, e.g. Gillingham et al. (2012). In particular, landlords have an incentive to buy inexpensive inefficient appliances when their tenants pay the utility bill. Although investments in more expensive technologies could, in theory, be passed on in the form of higher rents, it may be difficult for landlords to effectively convey this information to prospective tenants.

\subsection{Decomposition Analysis}

How much of the increase in electrification since 1950 can be explained by the five different hypotheses? As documented earlier, there has been a steady increase in the percentage of new homes heated with electricity. This section uses the estimates from the linear probability model to perform a decomposition analysis. The results from column (6) of Table 2 are used as the baseline specification, with results from alternative specifications reported for robustness.

The decomposition is performed as follows: (1) Choose one hypothesis and set the corresponding variables equal to 1950s levels. (2) Allow all other variables to evolve as they actually did over the period 1950-2018. (3) Predict electrification over the entire time period. (4) Compare predicted outcomes to actual outcomes. (5) Repeat the process for the other hypotheses. ${ }^{15}$

\footnotetext{
${ }^{15}$ A Blinder-Oaxaca decomposition probably does not make sense in this context. With BlinderOaxaca, the difference in means between two groups is decomposed into the parts that are due to
} 
Figure 5 plots the results of this decomposition. There are five panels, one for each hypothesis. The black line is the same in each panel - in each case plotting actual outcomes, i.e. the percentage of new homes in each year heated with electricity. The orange line differs across panels - in each case plotting predicted outcomes, holding fixed a different set of variables. For both the actual and predicted outcomes, a modest amount of smoothing has been applied to allow us to concentrate on the main overall pattern rather than idiosyncratic year-to-year fluctuations.

The single most important factor is energy prices. As the first panel illustrates, when energy prices are held fixed at 1950s levels, there is dramatically less adoption of electric heating during this 70-year period. Residential electricity prices fell sharply in real terms over this period, while residential natural gas and heating oil prices increased significantly. Had these changes not occurred, the model predicts that there would have been dramatically less electrification over this period.

Geography matters too. As shown earlier, there has been a pronounced shift in new housing construction toward warmer states. If one instead holds the distribution of population fixed at 1950s levels, the model predicts considerably less electrification over this time period.

Housing characteristics, climate, and income all have smaller impacts. The increased prevalence of multi-unit homes has worked to increase electrification, while the trend

differences in the mean values of the covariates, group differences in the effects of the covariates, and an unexplained component. This approach is less well-suited to explaining electrification because the groups are time periods so it would be necessary to somewhat arbitrarily select a "beginning" and "end" rather then attempting to explain the entire 70-year trajectory. In addition, with BlinderOaxaca the regressions are estimated separately by group, whereas for identification purposes it makes more sense in the electrification context to estimate a single integrated regression. 
toward larger homes works against electrification. Climate change has increased electrification, but the magnitude of the effect is modest. Finally, the large increase in average household income over this period is shown to have essentially zero effect on the increase in electrification.

Table 3 summarizes the results of the decomposition. The five factors explain $100 \%$ of the increase in electrification since 1950. Energy prices play a dominant role, explaining $82 \%$ of the increase. The changing geographic distribution of new home construction explains 11\%. Housing characteristics, climate, and income all have modest impacts.

\subsection{Alternative Specifications}

The results from the decomposition analysis are similar with alternative specifications of the linear probability model. See Table 4. Alternatives that were considered include using specifications from different columns in Table 2, more flexible functions of household income and HDDs, and specification including a lag and a lead for electricity prices. The latter specification is aimed at relaxing the assumption that choices are made only on the basis of current prices. See Appendix Table 1 for additional details. Overall, results are quite similar across specifications, with energy prices explaining $70 \%+$ of the increase in electrification throughout.

A couple of alternative specifications merit additional discussion. The instrumental variables specification is motivated by potential concerns about price endogeneity. As discussed earlier, there are several reasons why residential energy prices are unlikely 
to be driven by demand-side factors. Nonetheless, it is reassuring that the decomposition results are largely unchanged when prices are instrumented using lagged prices, crude oil prices, and wholesale-level natural gas and coal prices. See Appendix Table 2 for additional details.

Lastly, the specification excluding Northeastern states is motivated by potential concerns about the availability of natural gas. Previous work has shown that natural gas shortages from price controls were heavily concentrated in the Northeast (Davis, 2008). Between 1974 and 1978, for example, shortages precluded some households in Massachusetts from installing natural gas heating systems (Myers, 2019). Nonetheless, results are quite similar when predictions are compared only for the other three Census regions, implying that the results are not driven by the experience in the Northeast.

\section{The Cost of an Electrification Mandate}

\subsection{Background}

In this section, these data and framework are used to calculate the economic cost of an electrification mandate for new homes. As mentioned in the introduction, more than thirty jurisdictions in California, Washington, New York, Massachusetts, and Rhode Island have introduced natural gas bans, "electric-preferred" building codes, and other mandates aimed at requiring or strongly encouraging households to use electric heat. 
What would be the economic cost of an electrification mandate? The analysis in this section uses compensating variation to measure the change in consumer welfare from requiring households to choose electric heating. That is, how much income would households need to receive to make them indifferent between the current environment in which they can choose any heating system they would live and an electrification mandate?

A discrete choice model of residential heating is used for this analysis. The data and key variables are identical to the linear probability model described early. However, the discrete choice model makes a functional form assumption about the error term and other additional assumptions which make it possible to calculate the compensating variation in dollars. The modeling choices in this section are informed by a long history of economists using discrete choice models to describe household-level energy decisions, whether it be for air conditioning (Hausman, 1979), space heating (Dubin and McFadden, 1984; Dubin, 1985), or vehicles (Berry et al., 1995; Petrin, 2002; Bento et al., 2009).

In evaluating mandates for new homes, this analysis is also related to an existing literature on building codes. This literature has primarily focused on measuring the benefits of building codes, i.e. quantifying the energy savings from building codes (Aroonruengsawat et al., 2012; Jacobsen and Kotchen, 2013; Levinson, 2016; Kotchen, 2017). With electrification mandates the benefits can be relatively easily quantified using the carbon content of various fuels, but the costs are poorly understood. 


\subsection{Modeling Assumptions}

Households are assumed to choose which heating system to purchase by evaluating the following indirect utility function:

$$
u_{i j}=\alpha_{0 j}+\alpha_{1 j} p_{i j}+\alpha_{2 j} x_{i}+\epsilon_{i j}
$$

where $u_{i j}$ is the utility for household $i$ of heating system $j$. Since 2010,90\%+ of households choose electricity or natural gas for their primary heating system so the choice set is restricted to include only those two choices, $j \in\{e, g\}$ where $e$ and $g$ denote electric and natural gas heating systems, respectively. Preferences for heating system $j$ depend on energy prices $p_{i j}$, and a function of household characteristics $x_{i}$.

Households choose electric heating if $u_{i e}>u_{i g}$. Only differences in utility matter, so $\alpha_{0 g}$ and $\alpha_{2 g}$ are normalized to zero. Natural gas is thus selected as the baseline category and coefficients $\alpha_{0 e}$ and $\alpha_{2 e}$ can be interpreted relative to natural gas. Thus the indirect utility functions for electricity and natural gas can be expressed as follows:

$$
\begin{gathered}
u_{i e}=\alpha_{0 e}+\alpha_{1 e} p_{i e}+\alpha_{2 e} x_{i}+\epsilon_{i e}, \\
u_{i g}=\alpha_{1 g} p_{i g}+\epsilon_{i g} .
\end{gathered}
$$

The parameter $\alpha_{0 e}$ reflects the relative desirability of electric heating system, incorporating heating-system specific factors such as purchase and installation costs as well as preferences for particular heating systems that are common across house- 
holds. The parameters $\alpha_{1 e}$ and $\alpha_{1 g}$ reflect households' willingness to trade off the price per unit of energy against other heating system characteristics, and the parameter vector $\alpha_{2 e}$ describes interactions between household characteristics and heating system alternatives. This specification allows households living in cold climates to prefer natural gas heating systems, for example. Finally, the error terms, $\epsilon_{i e}$ and $\epsilon_{i g}$, capture unobserved differences across households' preferences for particular heating systems.

The error terms are assumed to be identically and independently distributed across households and heating systems with a type 1 extreme value distribution. Under this assumption, the probability that household $i$ selects electricity $e$ takes the well-known conditional logit form,

$$
P r_{i e}=\frac{\exp \left\{\alpha_{0 e}+\alpha_{1 e} p_{i e}+\alpha_{2 e} x_{i}\right\}}{\exp \left\{\alpha_{0 e}+\alpha_{1 e} p_{i e}+\alpha_{2 e} x_{i}\right\}+\exp \left\{\alpha_{1 g} p_{i g}\right\}}
$$

and the heating-system choice model can be estimated using maximum likelihood. In estimating the heating system choice model, the sample is restricted to homes built within the last ten years of ACS samples 2000, 2002, 2004, 2006, 2008, 2010, 2012, 2014, 2016, and 2018.

\subsection{Heating System Choice Estimates}

Table 5 reports coefficient estimates and standard errors from the heating system choice model. As expected, the coefficient estimates on prices are both negative. That is, higher electricity prices make electric heating less desirable, and higher 
natural gas prices make natural gas heating less desirable.

The overall tenor of the other estimates is very similar to the results from the linear probability model. For example, household income continues to not matter much, whereas heating degree days have a pronounced negative impact on the desirability of electric heating. Similarly, electric heating is less desirable for four- and five-

bedroom homes, and more desirable for rental homes, mobile homes, and multi-unit homes.

Figure 6 confirms that the predictions from the discrete choice model match closely the geographic pattern of electric heating. Panels (A) and (B) plot the actual and predicted proportions of households in each state selecting electric heating. Overall, there is close correspondence with low proportions of electric heating throughout the midwest and northeast, somewhat higher proportions throughout the west, and considerably higher proportions in the southwest and, in particular, in Florida.

\subsection{Calculating Reservation Prices}

The reservation price $p_{i}^{*}$ is defined as the price of electricity which makes household $i$ indifferent between the two choices. Equating $u_{i e}$ with $u_{i g}$ and solving for $p_{i}^{*}$ yields,

$$
p_{i}^{*}=\frac{\alpha_{1 g} p_{i g}-\alpha_{0 e}-\alpha_{2 e} x_{i}+\left(\epsilon_{i g}-\epsilon_{i e}\right)}{\alpha_{1 e}} .
$$

Thus the reservation price is a function of the price of natural gas $p_{i g}$, household characteristics and heating degree days $x_{i}$, model parameters $\alpha_{1 e}, \alpha_{1 g}, \alpha_{0 e}$, and $\alpha_{2 e}$, and the error terms, $\epsilon_{i e}$ and $\epsilon_{i g}$. For each of the more than one million households 
in the sample, error terms $\epsilon_{i e}$ and $\epsilon_{i g}$ are drawn from the extreme value distribution. These error terms are then used to calculate a reservation price for $p_{i}^{*}$ for each household.

Figure 7 plots average reservation prices by state. A household with a reservation price above their actual electricity price chooses electric heat, whereas a household with a reservation price below their actual electricity price chooses natural gas. Households in warm states tend to have high reservation prices so would prefer electric heat even when facing relatively high electricity prices. Households in cold states, however, require much lower or even negative electricity prices to be induced to select electric heating systems.

\subsection{Heating Demand Function}

U.S. households differ widely with regard to how much heat they consume. Climate conditions play a central role in these differences but housing characteristics, household demographics, income, and other factors matter as well. This section describes the approach used to estimate heating demand. The goal is to predict heating demand (in kilowatt hours) for all households in the sample. These predictions are then used in the following section to calculate compensating variation.

Both the Census and the ACS ask respondents how much they spend on electricity and natural gas. Although electricity is used for a wide-array of end uses, natural gas is used mostly for space and water heating. Accordingly, natural gas expenditures are used to construct the dependent variable for the heating demand function.In partic- 
ular, natural gas consumption in MMBTU (millions of Btu) is calculated by dividing natural gas expenditure by the price of natural gas in that state and year.

In estimating the heating demand function, the sample is restricted to homes built within the last ten years of ACS samples 2000, 2002, 2004, 2006, 2008, 2010, 2012, 2014, 2016, and 2018. This is the same restriction imposed for the heating system choice model in 4.2. In addition, the sample is further restricted to include only homes heated primarily with natural gas, to exclude homes reporting natural gas expenditure only for water heating, for example.

Table 6 reports coefficient estimates and standard errors. As expected, heating degree days are a strong determinant of heating demand. In addition, larger homes tend to use more heat, and multi-unit homes tend to use less heat. Household size and household income also influence heating demand. These estimates are used to predict heating demand for all households in the broader sample, including homes heated with natural gas as well as homes heated with electricity.

Appendix Figures 4 and 5 provide additional detail. Maps are presented showing state-level averages for predicted annual heating demand in MMBTU, as well as for predicted annual heating demand in kilowatt hours. This conversion is made assuming $100 \%$ efficiency for electric heating, $60 \%$ efficiency for natural gas heating ${ }^{16}$, and that each MMBTU is equal to 293 kilowatt hours. Finally, the figures also report

\footnotetext{
${ }^{16}$ Typical efficiency for a natural gas furnace is around $80 \%$. See e.g. Navigant Consulting "Residential End Uses: Historical Efficiency Data" Prepared for U.S. Energy Information Administration, 2015. In addition, with a forced air heating system there are additional 10 to 30 percent losses in the ducts which do not occur with electric resistance heating. See U.S. Energy Information Administration, "Duct Insulation: Heating and Cooling System Improvements", Accessed online December 2020.
} 
the implied annual expenditure for electric heating, based on electricity prices in each state.

\subsection{Compensating Variation}

Finally, compensating variation in dollars is calculated for each household,

$$
C V_{i}=\max \left\{\$ 0,\left(p_{i e}-p_{i}^{*}\right) * \text { Annual Consumption }{ }_{i}\right\}
$$

where Annual Consumption is predicted annual electricity consumption for heating from the previous subsection.

Compensating variation is zero for households with a reservation price above their actual electricity price, i.e. $p^{*}>p_{i e}$. These households are unaffected by an electrification mandate because they already prefer electric heating. For households with a reservation price below their actual electricity price, compensating variation depends on $p_{i e}, p^{*}$, and AnnualConsumption. The higher the current electricity price faced by a household, $p_{i e}$, the more that household must receive to be indifferent between the current environment and an electrification mandate. Similarly, the lower the $p^{*}$, the more the household prefers natural gas, and thus the more that household must receive. Finally, the higher the overall level of consumption, Annual Consumption, the more the household must receive.

Figure 8 illustrates the geographic pattern of compensating variation. For each state, the map describes the average annual income each household must receive to make them indifferent between the current environment and an electrification mandate. 
Appendix Table 3 presents the same information in table form.

Households in warm states like Florida, Texas, and throughout the Southeast are close to indifferent between electric and natural gas heating, so would be made worse off by less than $\$ 500$ annually on average. Households in Florida, for example, already tend to select electric heating so the average compensating variation is only \$85. Because it is more temperate, the west coast also tends to have lower levels of compensating variation: $\$ 1100$ in California, $\$ 1000$ in Oregon, and $\$ 1200$ in Washington.

Household in cold states, however, tend to strongly prefer natural gas so would be made worse off by $\$ 2000+$ annually on average by an electrification mandate. This includes relatively populous states like Ohio, Pennsylvania, and Illinois. In particularly cold states like New York, Massachusetts, and Michigan, willingnessto-pay is above $\$ 3000+$ annually. Finally, in Maine, Vermont, and New Hampshire average willingness-to-pay is above $\$ 4,000$ on average.

These maps obscure considerably heterogeneity within states. For example, one of the findings from the analysis is that multi-unit homes are considerably more likely to use electricity. From a compensating variation perspective, these multi-unit homes are low hanging fruit for electrification mandates because these housing units are already good candidates for electricity. On the opposite end of the spectrum, larger for homes (e.g. $4+$ bedrooms) are considerably less likely to use electricity, and thus households in these homes have a higher willingness-to-pay to avoid an electrification mandate. 


\subsection{Discussion}

Before proceeding, it is important to note several caveats. First, these estimates depend on the parametric assumptions of the model. The conditional logit model makes strong assumptions about the functional form for the error term, for example. In addition, the model makes strong parametric assumptions about $u_{i j}$ being linear in prices and other covariates. To the extent that these assumptions are violated, the estimates of compensating variation will be biased.

Second, the model is estimated using historical data, and thus cannot speak to how these tradeoffs will be affected in the future by technological change. Over this time period, there has been relatively little technological innovation in natural gas or conventional electric heating. However, electric heat pumps have become more energy-efficient and are expected to continue becoming more energy-efficient in the future. ${ }^{17}$ Proponents of electrification argue that heat pumps can be cost-effective for many households, particularly in warmer parts of the United States where heat pumps can operate more efficiently.

Third, no attempt has been made to explicitly model household demand for cooking, hot water heating, or other end uses. In part, this reflects data limitations. Since 1980, neither the Census nor ACS collect data on fuels used for cooking or water heating. That said, the focus on electrification of space heating makes sense given

\footnotetext{
${ }^{17}$ Kaufman et al. (2019) assume a 30\% increase in energy-efficiency (COP) for air source electric heat pumps between now and mid 2030s. Whereas electric resistance heating converts electricity into heat, a heat pump uses electricity to move heat from a cool space to a warm space, and thus can be used for both heating and cooling. Heat pumps have become more energy-efficient along with refrigerators and other compressor-based appliances.
} 
that this is by far the largest component of on-site fossil fuel consumption. Moreover, many households view these as bundled choices, for example, selecting natural gas for both space and water heating. ${ }^{18}$ To the extent that these decisions are bundled or at least highly correlated choices then the model and estimates of compensating variation can be viewed as measuring willingness-to-pay for the entire bundle.

\section{Conclusion}

Policymakers are increasingly turning to building electrification to reduce carbon dioxide emissions and other negative externalities. Missing from this discussion, however, is that electrification has already been happening in some sectors. This paper focuses on an important sector where electrification has already been happening, mostly without any policy intervention, over the last 70 years.

The core dataset for this analysis was compiled using household-level energy choices from millions of U.S. households in the Census and American Community Survey. The paper documents dramatic growth in residential electric heating - from only $1 \%$ of homes in 1950 , to $8 \%$ in 1970 , to $26 \%$ in 1990 , to $39 \%$ in 2018 . This growth in electrification has received very little attention from economists or other researchers.

This paper asked two research questions: (1) What explains the large increase in electrification of U.S. residential heating since 1950? and (2) How much would U.S.

\footnotetext{
${ }^{18}$ According to the author's calculations using the 2015 Residential Energy Consumption Survey, among households who heat with natural gas, $86 \%$ also use natural gas for water heating. Moreover, among households who heat with electricity, $82 \%$ also use electricity for water heating.
} 
households be willing-to-pay to avoid an electrification mandate?

The paper proposed and tested five hypotheses. Of the five possible explanations, energy prices turn out to be by far the most important factor, explaining $70 \%+$ of the increase in electrification over this period. This finding underscores the importance of pricing energy efficiently, a central theme in the broader literature in energy economics (Sherman and Visscher, 1982; Naughton, 1986; Davis and Muehlegger, 2010; Borenstein and Davis, 2012; Borenstein and Bushnell, 2018).

Geography, climate change, and housing characteristics are also shown to matter, collectively explaining about $20 \%$ of the increase in electrification. Household income growth, in contrast, is shown to have almost zero effect on electrification. This last finding suggests that it will not be harder, nor will it be easier, for policies to encourage electrification in lower-income communities.

Finally, a discrete choice model is estimated to measure household willingness-to-pay to avoid an an electrification mandate for new homes. Households in warm states are shown to be close to indifferent between electricity and natural gas, so would be made worse off by less than $\$ 500$ on average annually by being forced to use electricity. Households in cold states, however, tend to strongly prefer natural gas so would be made worse off by $\$ 2000$ or more annually.

These results have direct implications for emerging policies aimed at electrification. A substantial existing literature quantifies the economic benefits of fossil fuel abatement. Those benefits can be compared to the costs estimated here to determine where and when electrification mandates would pass a cost-benefit test. 
These measures of willingness-to-pay also shed light on how large a subsidy would be required to induce households to choose electric heating. In general, much smaller subsidies would be necessary in warmer states. In addition, the analysis highlights smaller homes and multi-unit homes as considerable opportunities for relatively lower-cost electrification.

One implication of the research is that, nationally, it may be a lot easier than is generally believed to encourage electrification. While short of what the United States would need for deep decarbonization, this steady historical trend over the last seven decades means that millions of U.S. households have already electrified. Moreover, the analysis identifies large numbers of additional households for whom adopting electric heating would impose relatively modest costs. 


\section{References}

Aas, Dan, Amber Mahone, Zack Subin, Michael Mac Kinnon, Blake Lane, and Snuller Price, "The Challenge of Retail Gas in California's Low-Carbon Future: Technology Options, Customer Costs, and Public Health Benefits of Reducing Natural Gas Use," Prepared by Energy and Environmental Economics (E3) for the California Energy Commission, Energy Research and Development Division, Final Project Report, 2020, CEC-500-2019-055-F.

Allcott, Hunt and Michael Greenstone, "Is There an Energy Efficiency Gap?," Journal of Economic Perspectives, 2012, 26 (1), 3-28.

- and Nathan Wozny, "Gasoline Prices, Fuel Economy, and the Energy Paradox," Review of Economics and Statistics, 2014, 96 (5), 779-795.

Alvarez, Ramón A, Daniel Zavala-Araiza, David $\mathbf{R}$ Lyon, David $\mathbf{T}$ Allen, Zachary R Barkley, Adam R Brandt, Kenneth J Davis, Scott C Herndon, Daniel J Jacob, Anna Karion et al., "Assessment of Methane Emissions from the US Oil and Gas Supply Chain," Science, 2018, 361 (6398), 186-188.

American Gas Association, "Gas Facts: A Statistical Record of the Gas Utility," Lexington, NY: American Gas Association, 1950-1969.

Anderson, Soren T, Ryan Kellogg, and James M Sallee, "What do Consumers Believe about Future Gasoline Prices?," Journal of Environmental Economics and Management, 2013, 66 (3), 383-403.

Aroonruengsawat, Anin, Maximilian Auffhammer, and Alan H Sanstad, "The Impact of State Level Building Codes on Residential Electricity Consumption," Energy Journal, 2012, 33 (1), 31.

Bento, Antonio M, Lawrence $\mathbf{H}$ Goulder, Mark R Jacobsen, and Roger H Von Haefen, "Distributional and Efficiency Impacts of Increased U.S. Gasoline Taxes," American Economic Review, 2009, 99 (3), 667-699.

Berry, Steven, James Levinsohn, and Ariel Pakes, "Automobile Prices in Market Equilibrium," Econometrica, 1995, 63 (4), 841-890.

Billimoria, Sherri, Mike Henchen, Leia Guccione, and Leah Louis-Prescott, "The Economics of Electrifying Buildings: How Electric Space and Water Heating Supports Decarbonization of Residential Buildings," Rocky Mountain Institute, 2018, insights/reports/economics-electrifying-buildings/.

Borenstein, Severin and James B Bushnell, "Do Two Electricity Pricing Wrongs Make a Right? Cost Recovery, Externalities, and Efficiency," National Bureau of Economic Research Working Paper, 2018. 
- and Lucas W. Davis, "The Equity and Efficiency of Two-Part Tariffs in US Natural Gas Markets," Journal of Law and Economics, 2012, 55 (1), 75-128.

Busse, Meghan R, Christopher R Knittel, and Florian Zettelmeyer, "Are Consumers Myopic? Evidence from New and Used Car Purchases," American Economic Review, 2013, 103 (1), 220-56.

Davis, Lucas W, "Durable Goods and Residential Demand for Energy and Water: Evidence from a Field Trial," RAND Journal of Economics, 2008, 39 (2), 530-546.

_ and Erich Muehlegger, "Do Americans Consume Too Little Natural Gas? An Empirical Test of Marginal Cost Pricing," RAND Journal of Economics, 2010, 41 (4), 791-810.

- and Lutz Kilian, "The Allocative Cost of Price Ceilings in the U.S. Residential Market for Natural Gas," Journal of Political Economy, 2011, 119 (2), 212-241.

Dubin, Jeffrey A, Consumer Durable Choice and the Demand for Electricity, Amsterdam: North Holland, 1985.

- and Daniel L McFadden, "An Econometric Analysis of Residential Electric Appliance Holdings and Consumption," Econometrica, 1984, 52 (2), 345-362.

Edison Electric Institute, "Statistical Year Book of the Electric Utility Industry," New York: Edison Electric Institute, 1950-1969.

Gerarden, Todd D, Richard G Newell, and Robert N Stavins, "Assessing the Energy-Efficiency Gap," Journal of Economic Literature, 2017, 55 (4), 1486-1525.

Gillingham, Kenneth and Karen Palmer, "Bridging the Energy Efficiency Gap: Policy Insights from Economic Theory and Empirical Evidence," Review of Environmental Economics and Policy, 2014, 8 (1), 18-38.

_, Matthew Harding, and David Rapson, "Split Incentives in Residential Energy Consumption," Energy Journal, 2012, 33 (2).

Hausman, Jerry A, "Individual Discount Rates and the Purchase and Utilization of Energy-using Durables," Bell Journal of Economics, 1979, 10 (1), 33-54.

Holland, Stephen P, Erin T Mansur, Nicholas Z Muller, and Andrew J Yates, "Are There Environmental Benefits from Driving Electric Vehicles? The Importance of Local Factors," American Economic Review, 2016, 106 (12), 3700-3729.

$\ldots, \ldots, \ldots$, and _ , "Decompositions and Policy Consequences of an Extraordinary Decline in Air Pollution from Electricity Generation," American Economic Journal: Economic Policy, 2020, 12 (4), 244-274. 
Ito, Koichiro, "Do Consumers Respond to Marginal or Average Price? Evidence from Nonlinear Electricity Pricing," American Economic Review, 2014, 104 (2), 537-63.

Jacobsen, Grant D and Matthew J Kotchen, "Are Building Codes Effective at Saving Energy? Evidence from Residential Billing Data in Florida," Review of Economics and Statistics, 2013, 95 (1), 34-49.

Kaufman, Noah, David Sandalow, Clotilde Rossi Di Schio, and Jake Higdon, "Decarbonoizing Space Heating with Air Source Heat Pumps," Columbia SIPA Working Paper, 2019.

Kotchen, Matthew J, "Longer-Run Evidence on Whether Building Energy Codes Reduce Residential Energy Consumption," Journal of the Association of Environmental and Resource Economists, 2017, 4 (1), 135-153.

Levinson, Arik, "How Much Energy do Building Energy Codes Save? Evidence from California houses," American Economic Review, 2016, 106 (10), 2867-2894.

Llewellyn, Garth T, Frank Dorman, JL Westland, D Yoxtheimer, Paul Grieve, Todd Sowers, E Humston-Fulmer, and Susan L Brantley, "Evaluating a Groundwater Supply Contamination Incident Attributed to Marcellus Shale Gas Development," Proceedings of the National Academy of Sciences, 2015, 112 (20), 6325-6330.

Mahone, Amber, Zachary Subin, Gabe Mantegna, Rawley Loken, Clea Kolster, and Niki Lintmeijer, "Achieving Carbon Neutrality in California: PATHWAYS Scenarios Developed for the California Air Resources Board," Prepared by Energy and Environmental Economics (E3) for the California Air Resources Board, 2020.

Mansur, Erin T, Robert Mendelsohn, and Wendy Morrison, "Climate Change Adaptation: A Study of Fuel Choice and Consumption in the U.S. Energy Sector," Journal of Environmental Economics and Management, 2008, 55 (2), 175-193.

McKain, Kathryn, Adrian Down, Steve M Raciti, John Budney, Lucy R Hutyra, Cody Floerchinger, Scott C Herndon, Thomas Nehrkorn, Mark S Zahniser, Robert B Jackson et al., "Methane Emissions from Natural Gas Infrastructure and Use in the Urban Region of Boston, Massachusetts," Proceedings of the National Academy of Sciences, 2015, 112 (7), 1941-1946.

Myers, Erica, "Are Home Buyers Inattentive? Evidence from Capitalization of Energy Costs," American Economic Journal: Economic Policy, 2019, 11 (2), 165-88.

Naughton, Michael C, "The Efficiency and Equity Consequences of Two-Part Tariffs in Electricity Pricing," Review of Economics and Statistics, 1986, 68 (3), 406-414.

NOAA National Centers for Environmental information, "Climate at a Glance: Statewide Time Series," https://www.ncdc.noaa.gov/cag/, 2020. 
Olmstead, Sheila M, Lucija A Muehlenbachs, Jhih-Shyang Shih, Ziyan Chu, and Alan J Krupnick, "Shale Gas Development Impacts on Surface Water Quality in Pennsylvania," Proceedings of the National Academy of Sciences, 2013, 110 (13), 4962 4967.

Petrin, Amil, "Quantifying the Benefits of New products: The Case of the Minivan," Journal of Political Economy, 2002, 110 (4), 705-729.

Platts Oil, "Platt's Oil Price Handbook and Oilmanac," New York, NY: Platts Oil, 19501969.

Rapson, David, "Durable Goods and Long-Run Electricity Demand: Evidence from Air Conditioner Purchase Behavior," Journal of Environmental Economics and Management, 2014, 68 (1), 141-160.

Reiss, Peter C and Matthew W White, "Household Electricity Demand, Revisited," Review of Economic Studies, 2005, 72 (3), 853-883.

_ and _, "What Changes Energy Consumption? Prices and Public Pressures," RAND Journal of Economics, 2008, 39 (3), 636-663.

Ruggles, Steven, Sarah Flood, Ronald Goeken, Josiah Grover, Erin Meyer, Jose Pacas, and Matthew Sobek, "IPUMS USA: Version 10.0," Minneapolis, MN: IPUMS, 2020.

Sahari, Anna, "Electricity Prices and Consumers' Long-term Technology Choices: Evidence from Heating Investments," European Economic Review, 2019, 114, 19-53.

Sherman, Roger and Michael Visscher, "Rate-of-Return Regulation and Two-Part Tariffs," Quarterly Journal of Economics, 1982, 97 (1), 27-42.

U.S. Department of Energy, Energy Information Administration, "State Energy Data System (SEDS)," Residential Sector Energy Price Estimates, 1970-2018. 
Figure 1: Growth in Electric Heating
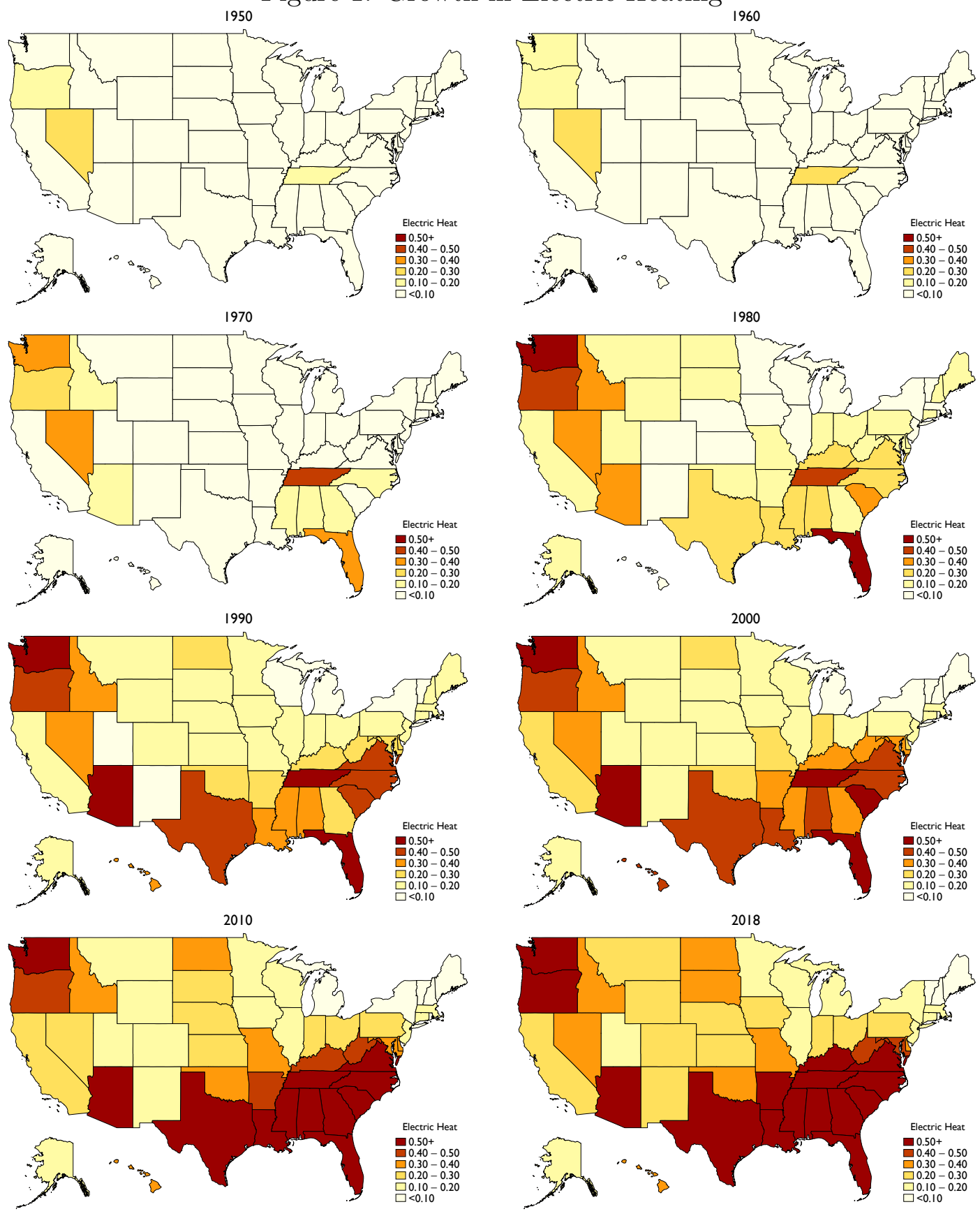


\section{Figure 2: U.S. Residential Energy Prices By State Since 1950}
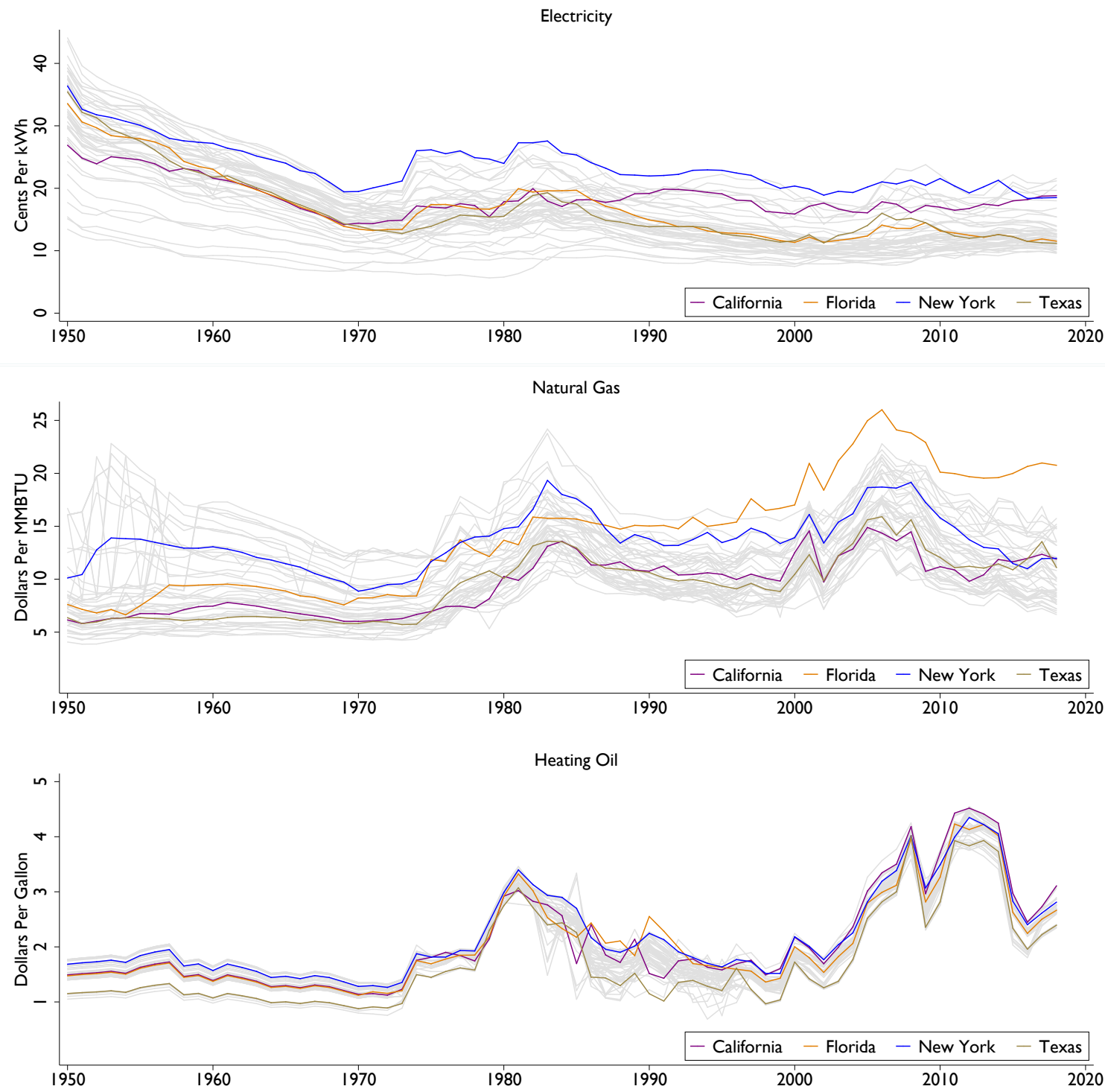

Notes: This figure plots average residential prices by state for electricity, natural gas, and heating oil. Prices are calculated as average annual revenue from residential sales and are plotted for all U.S. states except for Alaska and Hawaii. Data series are labeled for the four largest U.S. states by population (California, Texas, Florida, and New York). Data before 1970 come from Edison Electric Institute (1950-1969), American Gas Association (1950-1969), and Platts Oil (1950-1969), respectively. Data after 1970 come from U.S. Department of Energy, Energy Information Administration (1970-2018). Prices have been normalized to reflect year 2020 dollars. 
Figure 3: Decrease in Heating Degree Days Since 1950

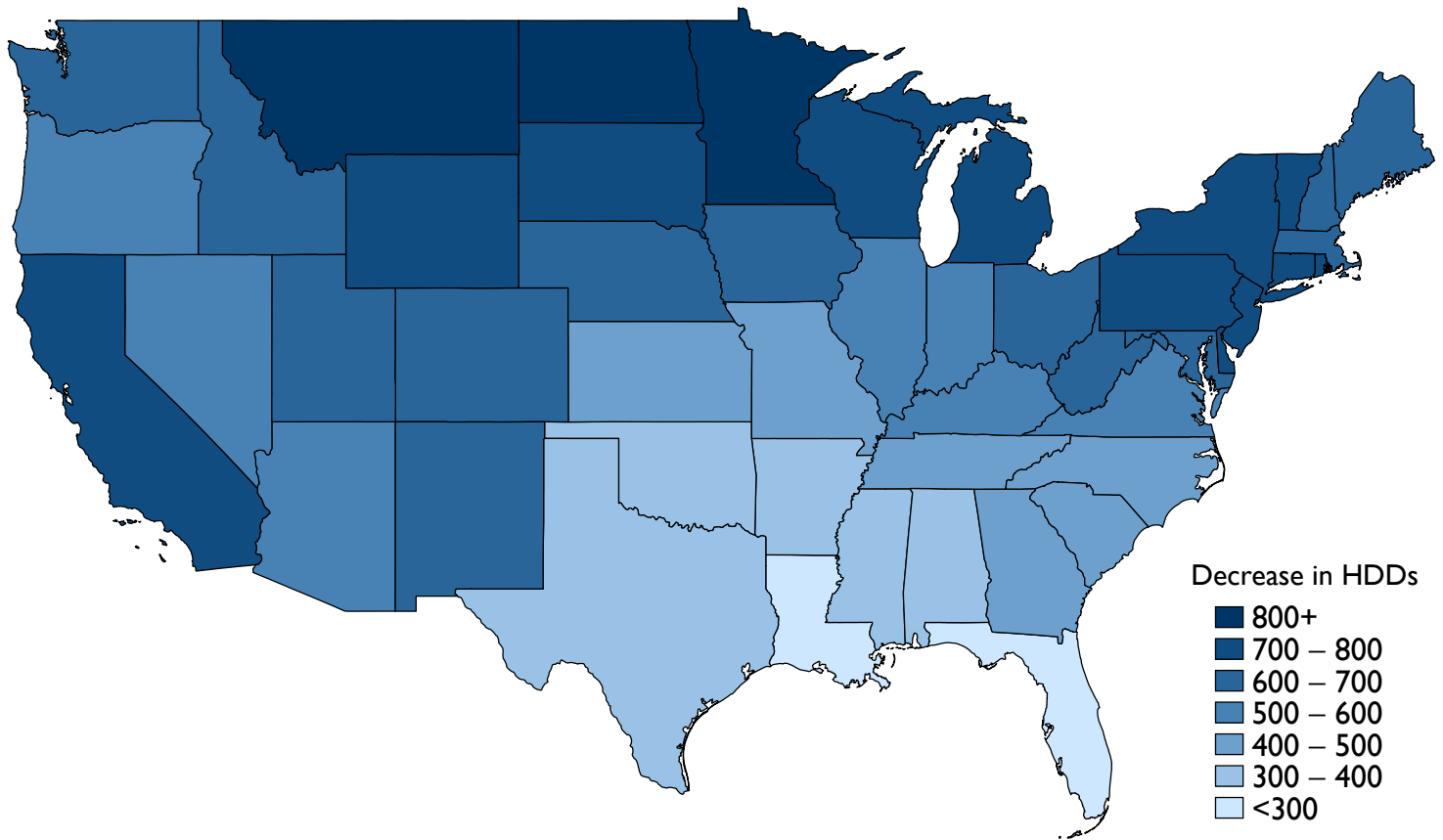

Notes: This figure describes the change in annual heating degree days (HDDs) between 1950 and 2019. For example, Minnesota had 9,300 HDDs in 1950 and 8,400 HDDs in 2019, for a decrease of 900 HDDs. Florida, in contrast, had 800 HDDs in 1950 and 600 HDDs in 2019, for a decrease of 200 HDDs. This is based on annual state-level data from NOAA National Centers for Environmental information (2020). However, rather than use the raw data which reflect a large amount of year-to-year variation, these calculates are based on fitted values from a linear time trend estimated separately by state. See Appendix Figure 2 for maps showing HDDs for each decade separately. 
Figure 4: Change in New Home Construction Since 1950s

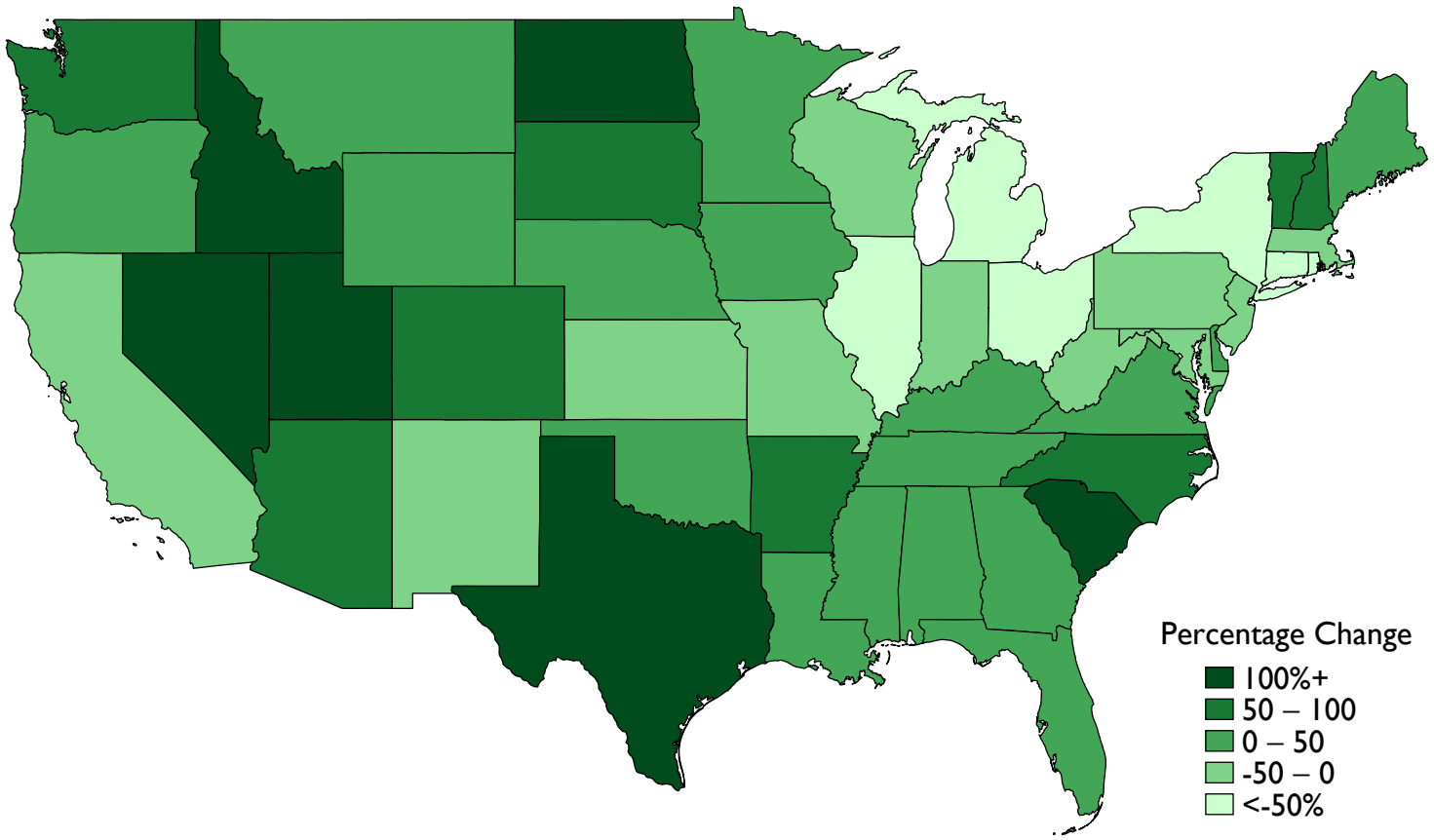

Notes: This figure describes how new home construction has changed at the state level between the 1950s and the 2010s. Specifically, the figure reports the percentage change in the percentage of new homes constructed in each state. For example, Texas had $7 \%$ of new home construction in the 1950 s, but $16 \%$ of new home construction in the 2010s, for a percentage increase of $130 \%$. California in contrast, had $14 \%$ of new home construction in the 1950s, and $7 \%$ of new home construction in the 2010 s, for a percentage decrease of $49 \%$. By this measure Rhode Island had the largest decrease $-70 \%$ while Nevada had the largest increase $+270 \%$. See Appendix Figure 3 for maps showing the distribution of new home construction for each decade separately. 
Figure 5: Percentage of New Homes Heated with Electricity, Decomposition
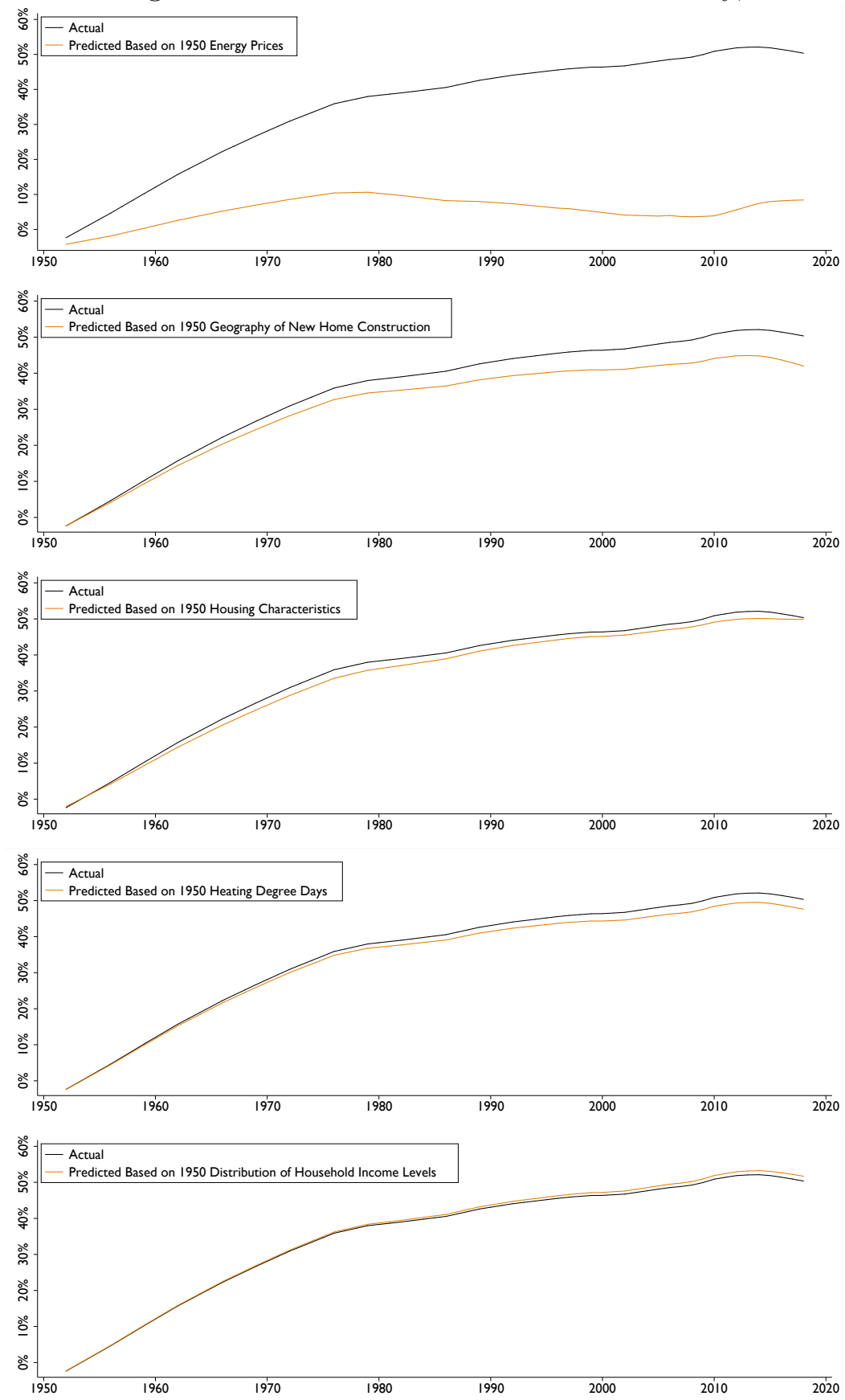
Figure 6: Evaluating the Fit of the Discrete Choice Model

A. Actual Heating System Choices

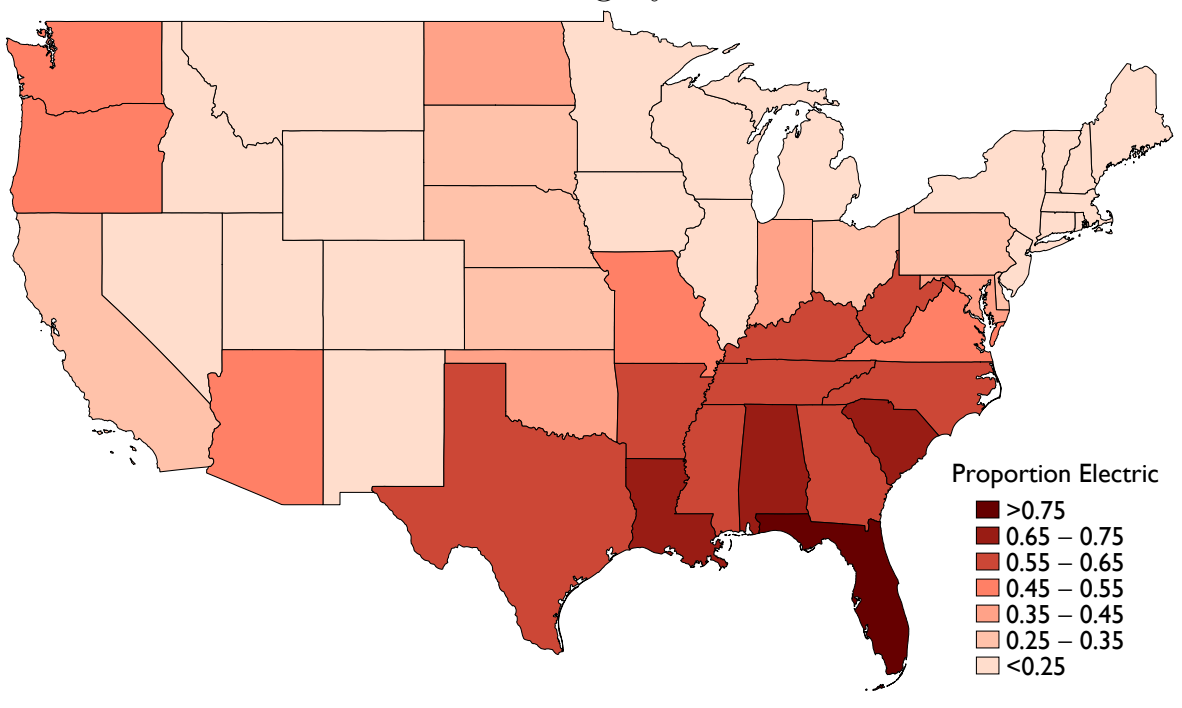

B. Predicted Heating System Choices

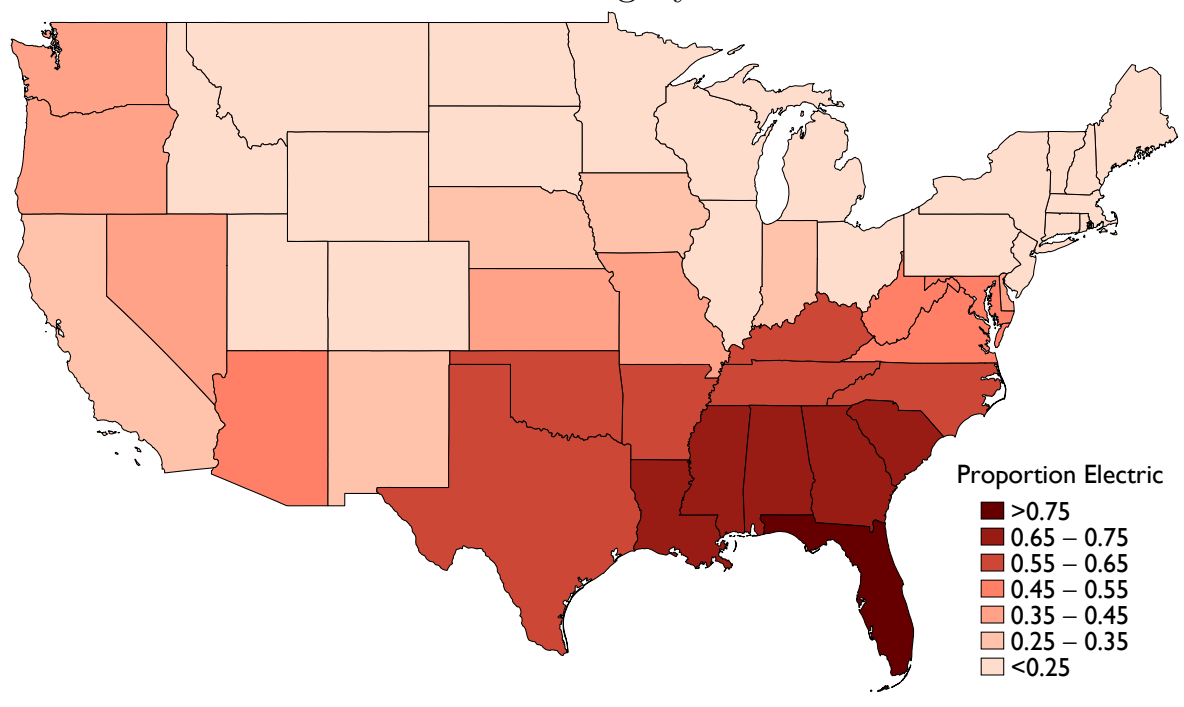


Figure 7: Average Reservation Price By State

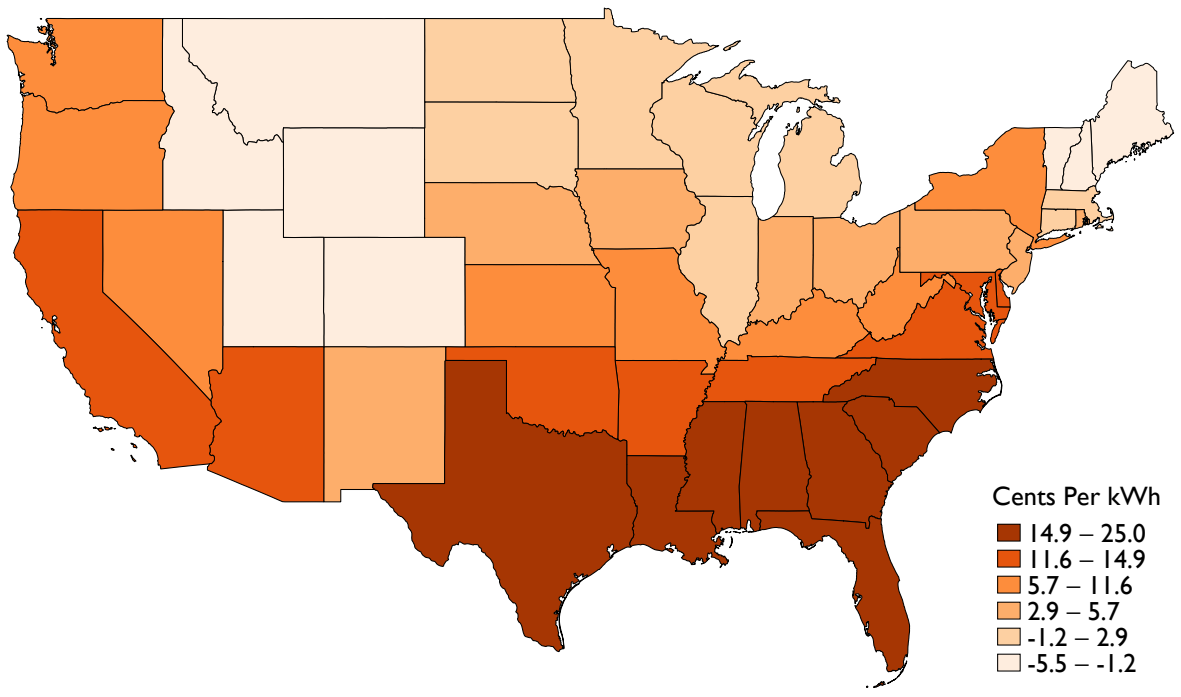

Figure 8: Willingness-to-Pay to Avoid an Electrification Mandate

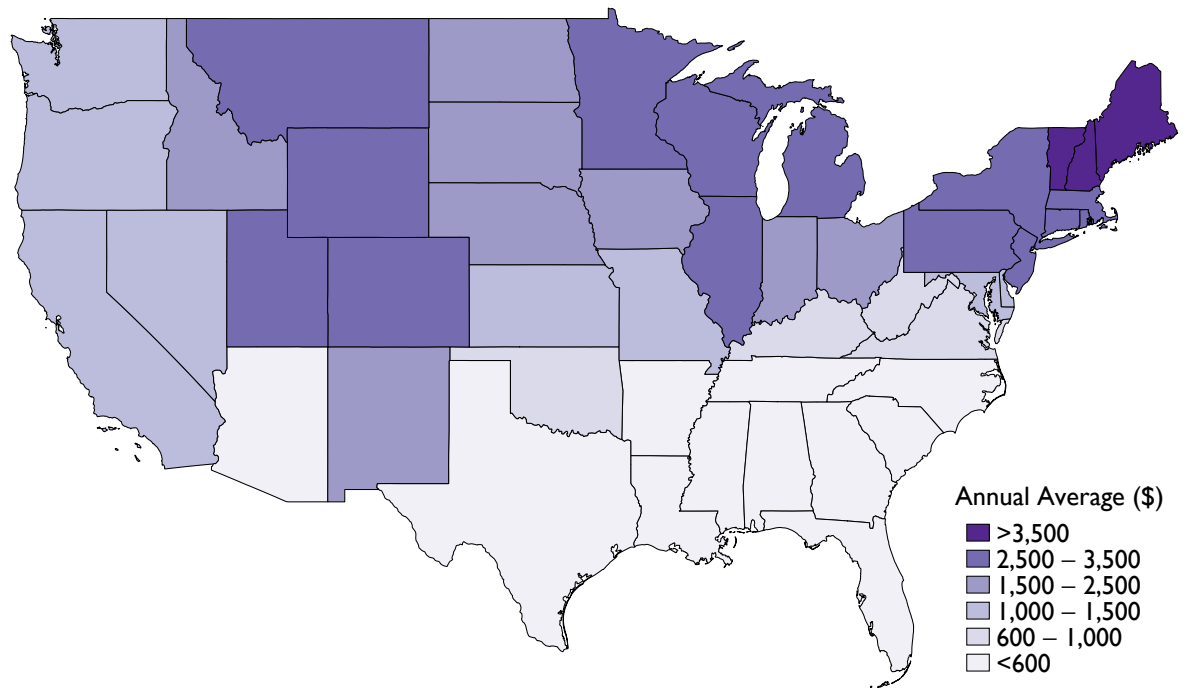


Table 1: Descriptive Statistics

\begin{tabular}{|c|c|c|c|c|c|c|c|}
\hline & $1950 \mathrm{~s}$ & $1960 \mathrm{~s}$ & $1970 \mathrm{~s}$ & $1980 \mathrm{~s}$ & $1990 \mathrm{~s}$ & $2000 \mathrm{~s}$ & $2010 \mathrm{~s}$ \\
\hline \multicolumn{8}{|c|}{ A. Primary Energy Source for Heating (percent) } \\
\hline Electricity & 4 & 18 & 41 & 47 & 42 & 45 & 53 \\
\hline Natural Gas & 53 & 56 & 40 & 37 & 44 & 45 & 39 \\
\hline Heating Oil & 32 & 17 & 8 & 4 & 3 & 2 & 1 \\
\hline Other & 12 & 8 & 11 & 11 & 10 & 8 & 7 \\
\hline \multicolumn{8}{|c|}{ B. Residential Energy Prices } \\
\hline Electricity (cents per kWh) & 25.8 & 18.7 & 15.3 & 17.6 & 13.7 & 12.2 & 13.0 \\
\hline Natural Gas (\$ per 1000 cuft) & 8.9 & 8.7 & 8.3 & 13.4 & 10.6 & 14.1 & 12.5 \\
\hline Heating Oil (\$ per gallon) & 1.6 & 1.3 & 1.5 & 2.4 & 1.6 & 2.2 & 3.5 \\
\hline \multicolumn{8}{|c|}{ C. Climate } \\
\hline Heating Degree Days, 1000s & 4.9 & 4.7 & 4.5 & 4.1 & 4.2 & 4.0 & 3.9 \\
\hline \multicolumn{8}{|c|}{ D. Percentage of New Homes By Region } \\
\hline Northeast & 19 & 17 & 13 & 13 & 10 & 9 & 10 \\
\hline Mid & 25 & 24 & 22 & 17 & 20 & 19 & 17 \\
\hline South & 34 & 38 & 42 & 47 & 47 & 48 & 52 \\
\hline West & 22 & 21 & 23 & 24 & 23 & 23 & 21 \\
\hline \multicolumn{8}{|c|}{ E. Household Demographics and Housing Characteristics } \\
\hline Household Income (1000s) & 61.0 & 73.9 & 65.8 & 79.9 & 97.9 & 99.3 & 106.4 \\
\hline wnership (percent) & 78 & 67 & 68 & 63 & 74 & 71 & 62 \\
\hline Multi-Unit (percent) & 19 & 27 & 29 & 30 & 20 & 22 & 31 \\
\hline Number of Bedrooms & 2.5 & 2.6 & 2.6 & 2.5 & 2.9 & 3.0 & 2.9 \\
\hline Number of Observations (1000s) & 144 & 159 & 1025 & 895 & 989 & 806 & 146 \\
\hline \multicolumn{8}{|c|}{$\begin{array}{l}\text { Note: This table reports descriptive statistics by decade of home construction. The es- } \\
\text { timation sample is restricted to homes built within } 10 \text { years of each Census or American } \\
\text { Community Survey. For example, homes built during the } 1950 \text { s are from the } 1960 \text { Census, } \\
\text { and homes built during the } 1960 \text { s are from the } 1970 \text { Census. Heating oil includes kerosene } \\
\text { and other liquid fuels. "Other" energy sources for heating include propane, coal, wood, as } \\
\text { well as homes with no heating. Prices and incomes have been normalized to reflect year } 2020 \\
\text { dollars. The sample sizes are smaller in the } 1960 \text { and } 1970 \text { censuses because only a random } \\
\text { subsample were asked about home heating. Observations are weighted using Census and } \\
\text { ACS sampling weights. }\end{array}$} \\
\hline
\end{tabular}


Table 2: Linear Probability Model, Estimates

\begin{tabular}{|c|c|c|c|c|c|c|}
\hline & $(1)$ & $(2)$ & $(3)$ & $(4)$ & $(5)$ & $(6)$ \\
\hline Electricity Price, in logs & $\begin{array}{c}-0.40^{* *} \\
(0.03)\end{array}$ & $\begin{array}{c}-0.43^{* *} \\
(0.04)\end{array}$ & $\begin{array}{c}-0.38^{* *} \\
(0.03)\end{array}$ & $\begin{array}{c}-0.40^{* *} \\
(0.05)\end{array}$ & $\begin{array}{c}-0.40^{* *} \\
(0.04)\end{array}$ & $\begin{array}{c}-0.42^{* *} \\
(0.06)\end{array}$ \\
\hline Natural Gas Price, in logs & $\begin{array}{l}0.21^{* *} \\
(0.06)\end{array}$ & $\begin{array}{l}0.29 * * \\
(0.08)\end{array}$ & $\begin{array}{l}0.18^{* *} \\
(0.05)\end{array}$ & $\begin{array}{l}0.24^{* *} \\
(0.07)\end{array}$ & $\begin{array}{l}0.15^{* *} \\
(0.05)\end{array}$ & $\begin{array}{l}0.21^{* *} \\
(0.07)\end{array}$ \\
\hline Heating Oil Price, in logs & $\begin{array}{c}0.04 \\
(0.04)\end{array}$ & $\begin{array}{l}-0.08 \\
(0.15)\end{array}$ & $\begin{array}{l}0.08^{*} \\
(0.03)\end{array}$ & $\begin{array}{c}0.08 \\
(0.10)\end{array}$ & $\begin{array}{l}0.09^{* *} \\
(0.03)\end{array}$ & $\begin{array}{c}0.06 \\
(0.10)\end{array}$ \\
\hline Household Income, 1000s & $\begin{array}{c}-0.00^{* *} \\
(0.00)\end{array}$ & $\begin{array}{c}-0.00^{* *} \\
(0.00)\end{array}$ & $\begin{array}{c}-0.00^{* *} \\
(0.00)\end{array}$ & $\begin{array}{c}-0.00^{* *} \\
(0.00)\end{array}$ & $\begin{array}{c}-0.00^{* *} \\
(0.00)\end{array}$ & $\begin{array}{c}-0.00^{* *} \\
(0.00)\end{array}$ \\
\hline Heating Degree Days, 1000s & $\begin{array}{c}-0.06^{* *} \\
(0.01)\end{array}$ & $\begin{array}{c}-0.06^{* *} \\
(0.01)\end{array}$ & $\begin{array}{c}-0.09^{* *} \\
(0.02)\end{array}$ & $\begin{array}{l}-0.04^{*} \\
(0.02)\end{array}$ & $\begin{array}{c}-0.05^{* *} \\
(0.01)\end{array}$ & $\begin{array}{c}-0.06^{* *} \\
(0.01)\end{array}$ \\
\hline Four Bedroom Home & $\begin{array}{c}-0.05^{* *} \\
(0.01)\end{array}$ & $\begin{array}{c}-0.05^{* *} \\
(0.01)\end{array}$ & $\begin{array}{c}-0.05^{* *} \\
(0.01)\end{array}$ & $\begin{array}{c}-0.04^{* *} \\
(0.01)\end{array}$ & $\begin{array}{c}-0.05^{* *} \\
(0.01)\end{array}$ & $\begin{array}{c}-0.05^{* *} \\
(0.01)\end{array}$ \\
\hline Five + Bedroom Home & $\begin{array}{c}-0.10^{* *} \\
(0.01)\end{array}$ & $\begin{array}{c}-0.08^{* *} \\
(0.01)\end{array}$ & $\begin{array}{c}-0.10^{* *} \\
(0.02)\end{array}$ & $\begin{array}{c}-0.08^{* *} \\
(0.02)\end{array}$ & $\begin{array}{c}-0.10^{* *} \\
(0.01)\end{array}$ & $\begin{array}{c}-0.08^{* *} \\
(0.02)\end{array}$ \\
\hline Rented, i.e. not owned & $\begin{array}{c}0.01 \\
(0.01)\end{array}$ & $\begin{array}{c}0.01 \\
(0.01)\end{array}$ & $\begin{array}{c}0.01 \\
(0.01)\end{array}$ & $\begin{array}{l}0.02^{*} \\
(0.01)\end{array}$ & $\begin{array}{l}0.02^{*} \\
(0.01)\end{array}$ & $\begin{array}{c}0.02^{* *} \\
(0.01)\end{array}$ \\
\hline Mobile Home & $\begin{array}{c}0.04 \\
(0.03)\end{array}$ & $\begin{array}{c}0.02 \\
(0.03)\end{array}$ & $\begin{array}{c}0.03 \\
(0.03)\end{array}$ & $\begin{array}{c}0.02 \\
(0.03)\end{array}$ & $\begin{array}{c}0.03 \\
(0.03)\end{array}$ & $\begin{array}{l}0.02 \\
(0.03)\end{array}$ \\
\hline Single Family, Attached & $\begin{array}{l}0.04^{*} \\
(0.02)\end{array}$ & $\begin{array}{l}0.04^{* *} \\
(0.01)\end{array}$ & $\begin{array}{l}0.04^{* *} \\
(0.01)\end{array}$ & $\begin{array}{l}0.04^{* *} \\
(0.01)\end{array}$ & $\begin{array}{l}0.04^{* *} \\
(0.01)\end{array}$ & $\begin{array}{l}0.03^{* *} \\
(0.01)\end{array}$ \\
\hline Multi-Unit Home, 2-4 Units & $\begin{array}{l}0.12^{* *} \\
(0.01)\end{array}$ & $\begin{array}{l}0.12^{* *} \\
(0.01)\end{array}$ & $\begin{array}{l}0.13^{* *} \\
(0.01)\end{array}$ & $\begin{array}{l}0.12^{* *} \\
(0.01)\end{array}$ & $\begin{array}{l}0.12^{* *} \\
(0.01)\end{array}$ & $\begin{array}{l}0.12^{* *} \\
(0.01)\end{array}$ \\
\hline Multi-Unit Home, $5+$ Units & $\begin{array}{l}0.25^{* *} \\
(0.02)\end{array}$ & $\begin{array}{l}0.24^{* *} \\
(0.02)\end{array}$ & $\begin{array}{c}0.25^{* *} \\
(0.02)\end{array}$ & $\begin{array}{l}0.24^{* *} \\
(0.02)\end{array}$ & $\begin{array}{l}0.25^{* *} \\
(0.02)\end{array}$ & $\begin{array}{c}0.24^{* *} \\
(0.02)\end{array}$ \\
\hline Year Fixed Effects & No & Yes & No & Yes & No & Yes \\
\hline Geographic Fixed Effects & No & No & Regions & Regions & Divisions & Divisions \\
\hline $\begin{array}{l}\text { Observations } \\
\text { R-squared }\end{array}$ & $\begin{array}{c}4,163,308 \\
0.26\end{array}$ & $\begin{array}{c}4,163,308 \\
0.28\end{array}$ & $\begin{array}{c}4,163,308 \\
0.27\end{array}$ & $\begin{array}{c}4,163,308 \\
0.28\end{array}$ & $\begin{array}{c}4,163,308 \\
0.27\end{array}$ & $\begin{array}{c}4,163,308 \\
0.29\end{array}$ \\
\hline
\end{tabular}

Note: This table reports coefficient estimates and standard errors from six separate least squares regressions. In all regressions the dependent variable is an indicator variable for homes for which electricity is the primary form of space heating. Region and division fixed effects refer to the four Census regions and nine Census divisions. Year fixed effects are indicator variables for the year the home was constructed. All regressions are estimated using Census and ACS sampling weights. Standard errors are clustered by state. ${ }^{* *}$ Significant at the $1 \%$ level, ${ }^{*}$ Significant at the $5 \%$ level. 
Table 3: What Explains the Increase in Electrification?

\begin{tabular}{lr}
\hline \hline Energy Prices & $82 \%$ \\
&
\end{tabular}

Geography

Housing

Climate

Household Income

Note: This table reports the percentage explained by the five hypotheses. This decomposition uses the regression estimates from Table 2, column 6. See Figure 5 for figures corresponding to these five counterfactual analyses. Standard errors in parentheses were estimated using a block bootstrap by state with 100 replications. 
Table 4: Alternative Specifications For Decomposition

\begin{tabular}{|c|c|c|c|c|c|c|}
\hline & Prices & Geography & Housing & Climate & Income & Total \\
\hline 1. Baseline Specification & $82 \%$ & $11 \%$ & $4 \%$ & $4 \%$ & $-1 \%$ & $100 \%$ \\
\hline 2. Census Region FEs & $84 \%$ & $7 \%$ & $4 \%$ & $3 \%$ & $-2 \%$ & $96 \%$ \\
\hline 3. Without Year FEs & $73 \%$ & $11 \%$ & $4 \%$ & $4 \%$ & $-2 \%$ & $90 \%$ \\
\hline 4. Cubics in Income and HDDs & $74 \%$ & $11 \%$ & $4 \%$ & $4 \%$ & $-1 \%$ & $92 \%$ \\
\hline 5. Including Lag and Lead & $80 \%$ & $11 \%$ & $5 \%$ & $4 \%$ & $-1 \%$ & $98 \%$ \\
\hline 6. Instrumental Variables & $73 \%$ & $11 \%$ & $5 \%$ & $4 \%$ & $-2 \%$ & $91 \%$ \\
\hline 7. Excluding the Northeast & $79 \%$ & $10 \%$ & $3 \%$ & $4 \%$ & $-1 \%$ & $95 \%$ \\
\hline \multicolumn{7}{|c|}{$\begin{array}{l}\text { Note: This table reports the percentage explained by the five hypotheses in the baseline specification and six alternative } \\
\text { specifications. The results in row (1) use the regression estimates from Table } 2 \text {, column } 6 \text {. Rows }(2) \text { and }(3) \text { use the } \\
\text { specifications reported in Table } 2 \text {, columns } 4 \text { and } 5 \text {, respectively. Row }(4) \text { adds third-order polynomials in household } \\
\text { income and heating degree days. Row }(5) \text { adds a one-year lag and a one-year lead for electricity prices. Row }(6) \text { uses the } \\
\text { instrumental variables specification with the full set of instruments. Finally, row ( } 7) \text { excludes the Northeast when comparing } \\
\text { predicted outcomes to actual outcomes. }\end{array}$} \\
\hline
\end{tabular}


Table 5: Heating System Choice Model

\begin{tabular}{|c|c|}
\hline $\begin{array}{l}\text { Electric Heating System x } \\
\text { Electricity Price (cents per kWh) } \\
\text { Natural Gas Heating System x } \\
\text { Natural Gas Price (\$ per } 1000 \text { cuft) }\end{array}$ & $\begin{array}{c}-0.15^{* *} \\
(0.03) \\
-0.07^{* *} \\
(0.01)\end{array}$ \\
\hline \multicolumn{2}{|l|}{ Electric Heating System x } \\
\hline Household Income, 1000s & $\begin{array}{c}-0.00^{* *} \\
(0.00)\end{array}$ \\
\hline Heating Degree Days, 1000s & $\begin{array}{c}-0.36^{* *} \\
(0.06)\end{array}$ \\
\hline Four Bedroom Home & $\begin{array}{c}-0.32^{* *} \\
(0.04)\end{array}$ \\
\hline Five+ Bedroom Home & $\begin{array}{c}-0.53^{* *} \\
(0.10)\end{array}$ \\
\hline Rented, i.e. not owner-occupied & $\begin{array}{l}0.40^{* *} \\
(0.05)\end{array}$ \\
\hline Mobile Home & $\begin{array}{c}0.90^{* *} \\
(0.12)\end{array}$ \\
\hline Single Family Home, Attached & $\begin{array}{l}-0.05 \\
(0.10)\end{array}$ \\
\hline Multi-Unit Home, 2-4 Units & $\begin{array}{l}0.71^{* *} \\
(0.07)\end{array}$ \\
\hline Multi-Unit Home, 5+ Units & $\begin{array}{l}1.31^{* *} \\
(0.09)\end{array}$ \\
\hline Constant & $\begin{array}{l}1.40 \\
(0.73)\end{array}$ \\
\hline \multicolumn{2}{|c|}{$\begin{array}{l}\text { Note: This table reports coefficient estimates and standard errors } \\
\text { from a conditional logit model estimated using maximum likeli- } \\
\text { hood with } 1,076,014 \text { observations. In addition to the variables } \\
\text { listed the model includes dummy variables for the nine Census } \\
\text { divisions. See the paper for details. The model is estimated using } \\
\text { ACS sampling weights. Standard errors are clustered by state. ** } \\
\text { Significant at the } 1 \% \text { level, *Significant at the } 5 \% \text { level. }\end{array}$} \\
\hline
\end{tabular}


Table 6: Heating Demand Function

\begin{tabular}{|c|c|c|}
\hline Heating Degree Days, 1000s & $23.56^{* *}$ & $(3.15)$ \\
\hline Heating Degree Days Squared & $-1.40^{* *}$ & $(0.35)$ \\
\hline Four Bedroom Home & $11.39^{* *}$ & $(1.49)$ \\
\hline Five+ Bedroom Home & $21.28^{* *}$ & $(1.97)$ \\
\hline Rented, i.e. not owner-occupied & -0.43 & $(1.49)$ \\
\hline Mobile Home & $-8.00^{* *}$ & $(2.45)$ \\
\hline Single Family Home, Attached & $-19.19^{* *}$ & $(1.74)$ \\
\hline Multi-Unit Home, 2-4 Units & $-16.96^{* *}$ & $(2.49)$ \\
\hline Multi-Unit Home, 5+ Units & $-36.30 * *$ & $(3.43)$ \\
\hline Two Household Members & $3.48^{* *}$ & $(0.49)$ \\
\hline Three Household Members & $10.15^{* *}$ & $(0.94)$ \\
\hline Four Household Members & $14.60^{* *}$ & $(1.08)$ \\
\hline Five Household Members & $17.80^{* *}$ & $(1.68)$ \\
\hline Six or More Members & $20.11^{* *}$ & $(2.34)$ \\
\hline Household Income, 1000s & $0.09^{* *}$ & $(0.01)$ \\
\hline Census Division Fixed Effects & Yes & \\
\hline Observations & 408,765 & \\
\hline R-squared & 0.13 & \\
\hline \multicolumn{3}{|c|}{$\begin{array}{l}\text { Note: This table reports coefficient estimates and standard errors from a single least } \\
\text { squares regression. The dependent variable is annual heating demand in millions of } \\
\text { Btu, mean }=95.2 \text {. The sample includes homes ten years old or less in the Ameri- } \\
\text { can Community Survey since } 2000 \text { heated primarily with natural gas. The model is } \\
\text { estimated using ACS sampling weights. Standard errors are clustered by state. ** } \\
\text { Significant at the } 1 \% \text { level, *Significant at the } 5 \% \text { level. }\end{array}$} \\
\hline
\end{tabular}


Appendix Figure 1: U.S. Residential Energy Prices in 2018 Electricity
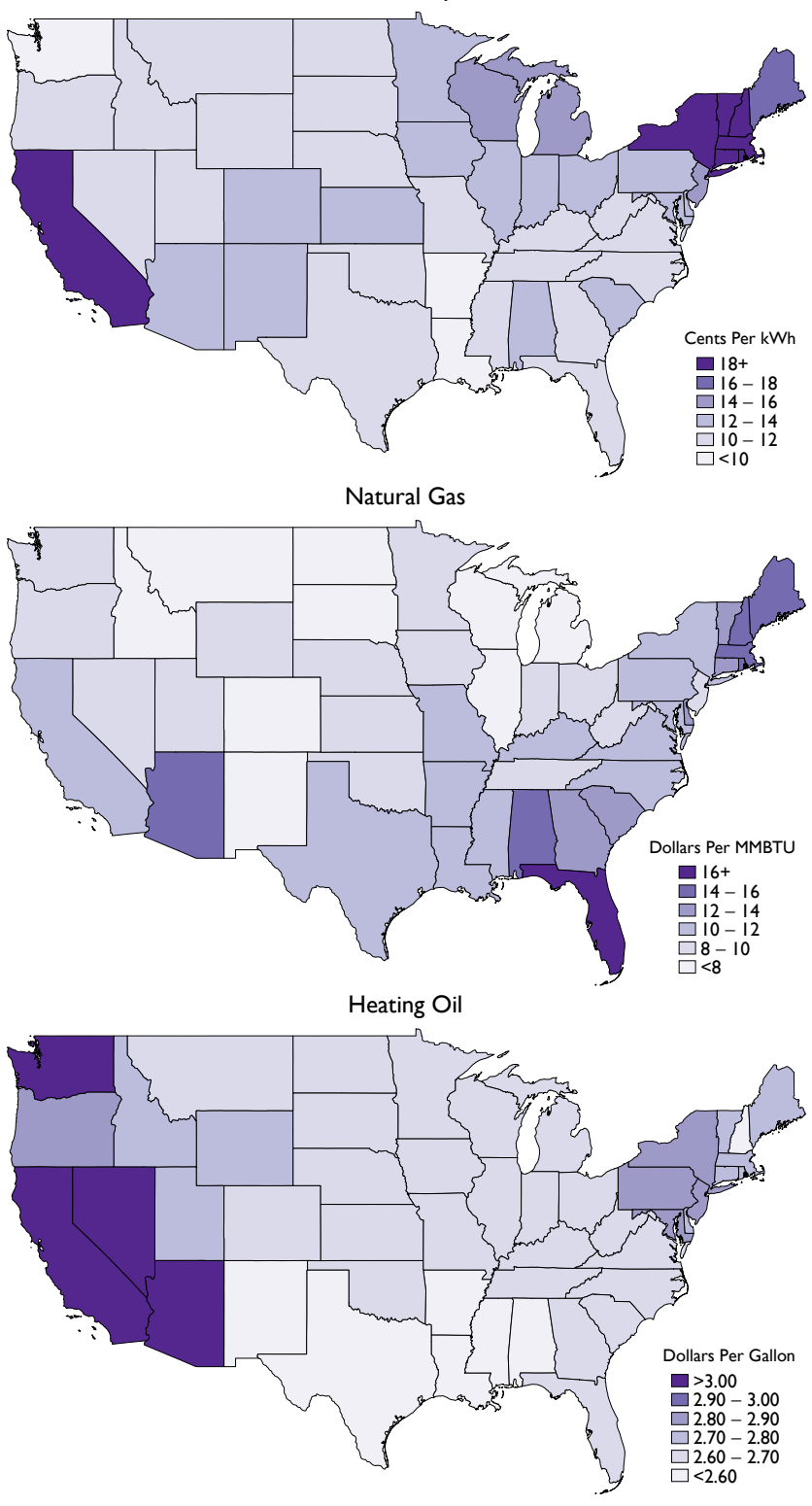
Appendix Figure 2: Heating Degree Days, By Decade
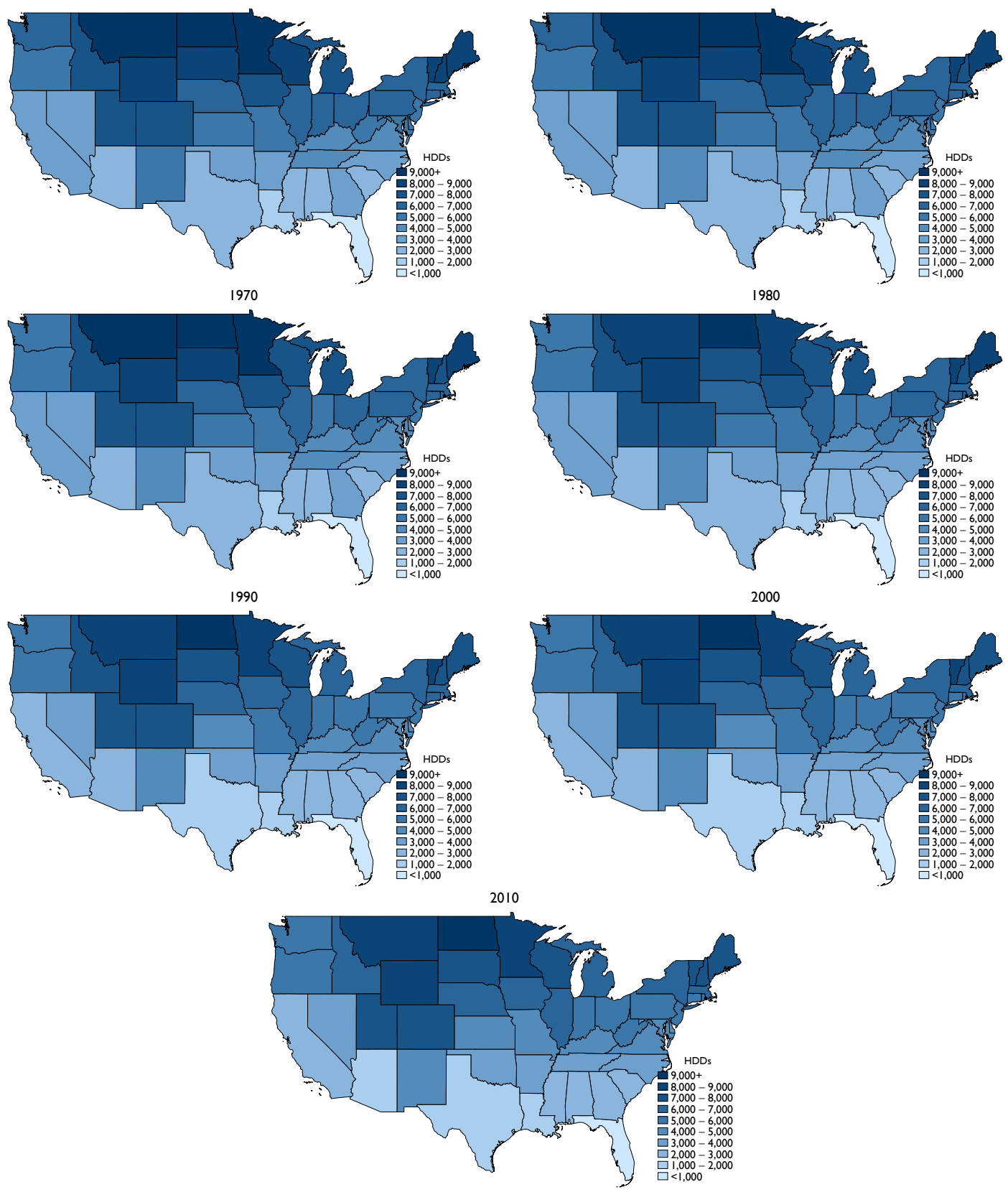
Appendix Figure 3: Percentage of New Homes in Each State, By Decade
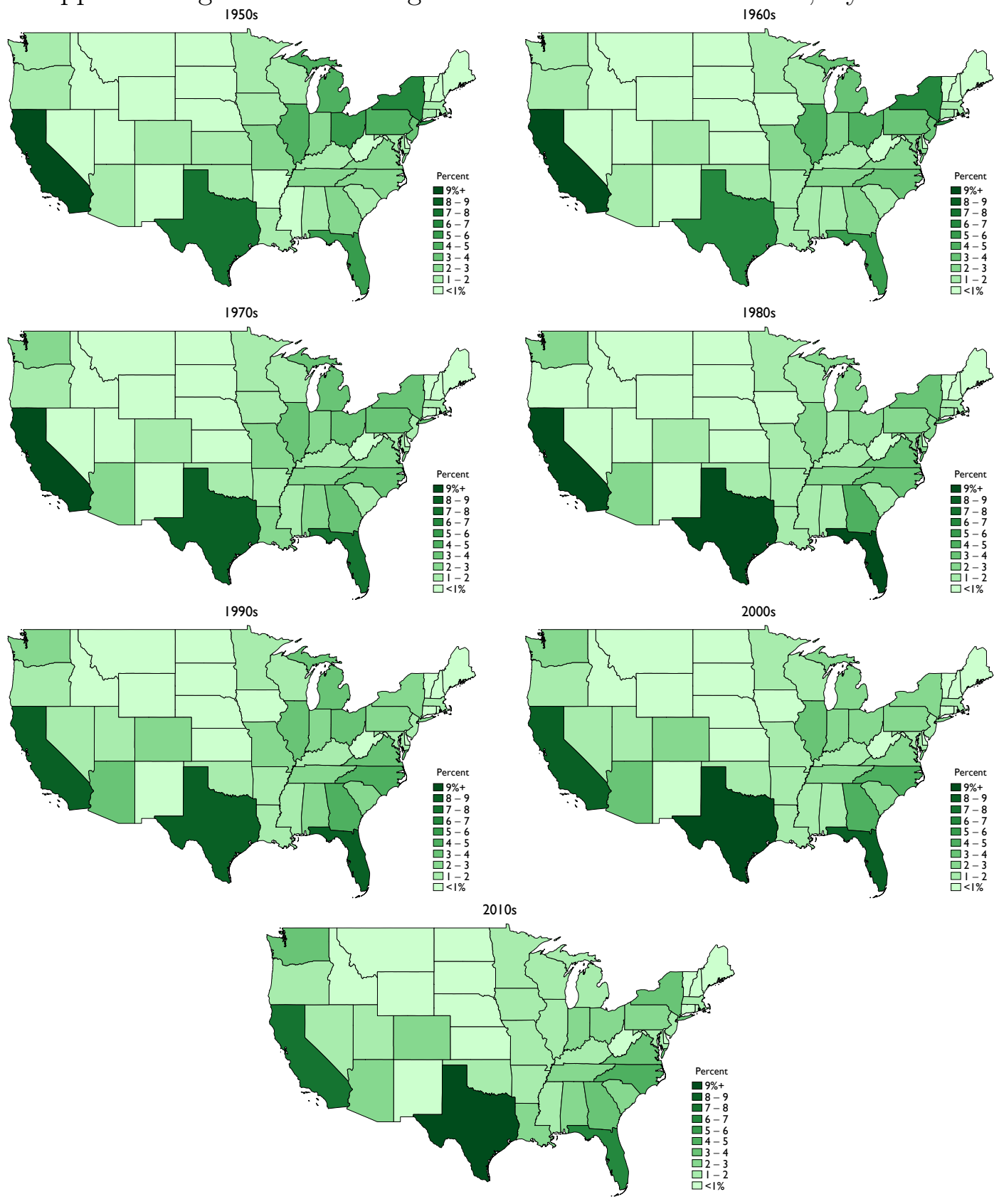
Appendix Figure 4: Calculating Compensating Variation, Intermediate Steps A. Annual Average Natural Gas Expenditure For Homes with Natural Gas Heat

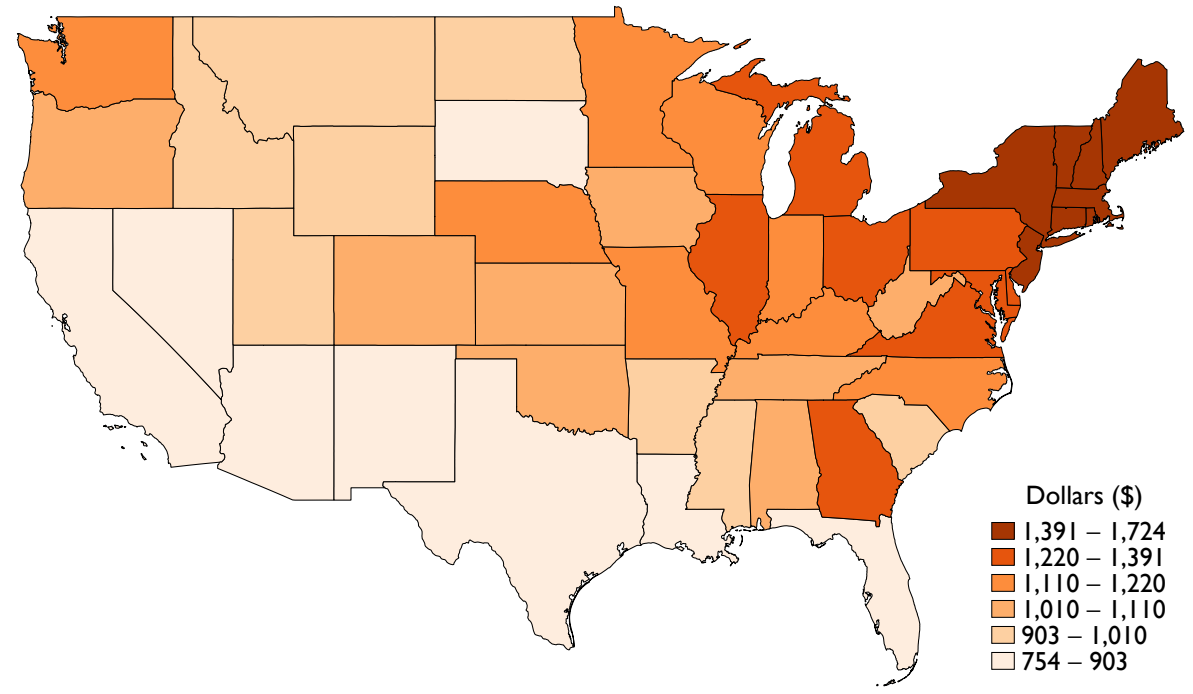

B. Predicted Annual Heating Demand in MMBTU

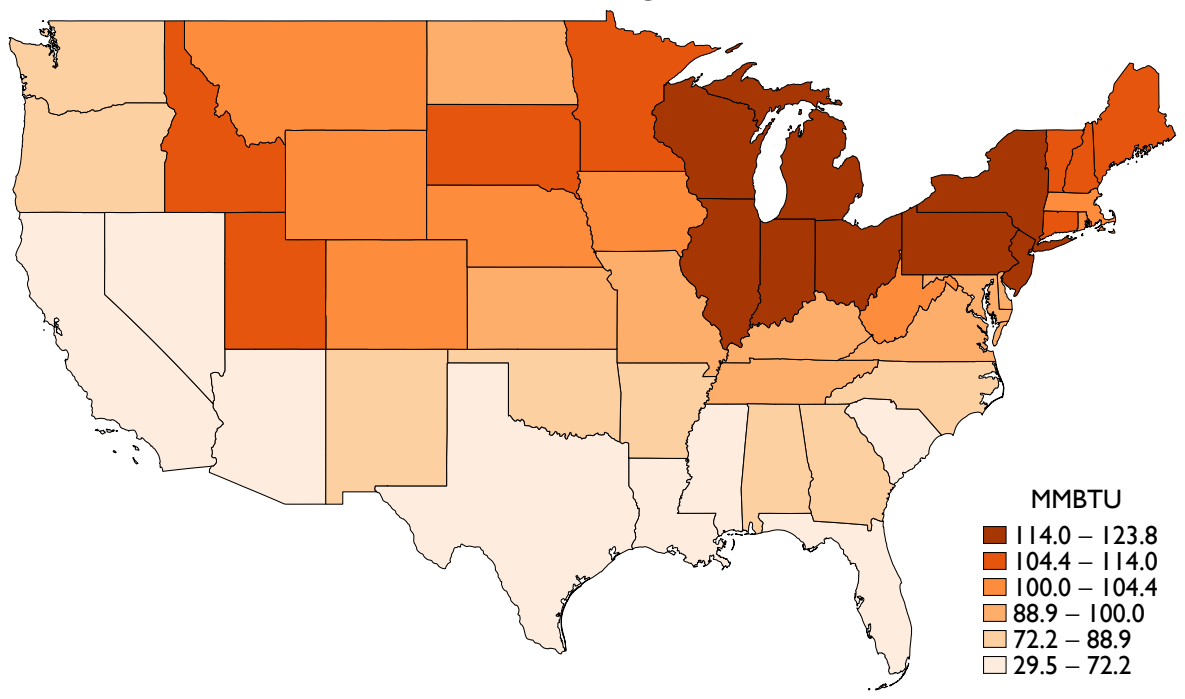


Appendix Figure 5: Calculating Compensating Variation, Intermediate Steps (Continued)

C. Predicted Annual Heating Demand in kWh

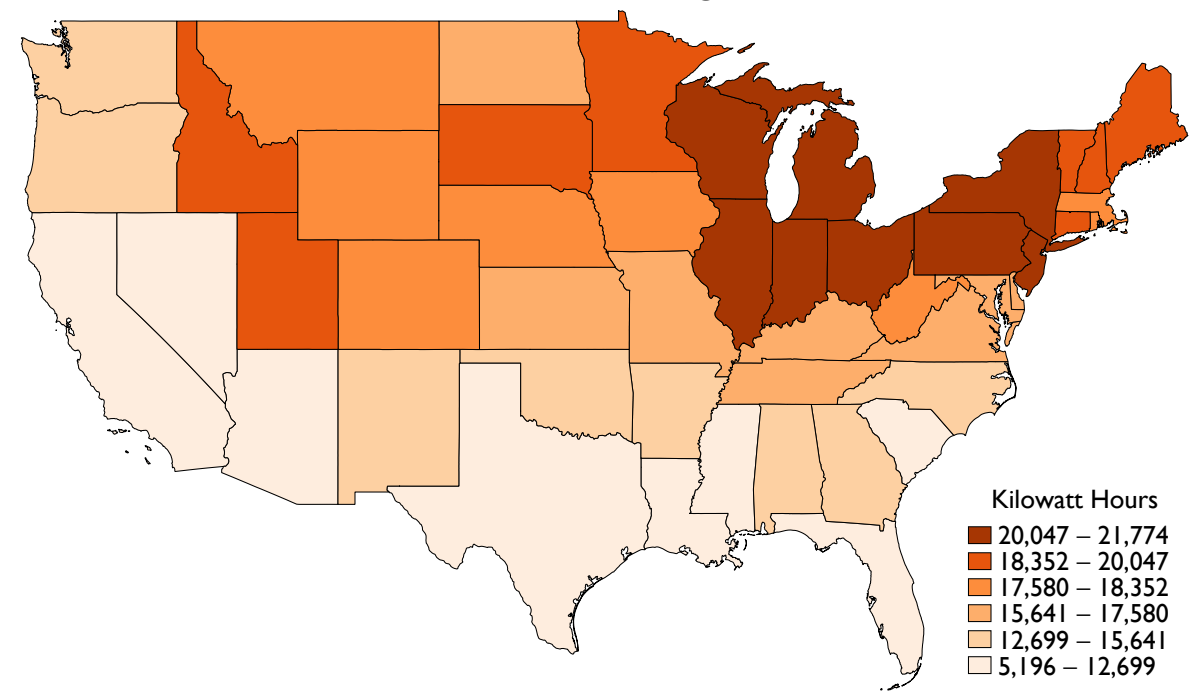

D. Implied Annual Expenditure for Electric Heating

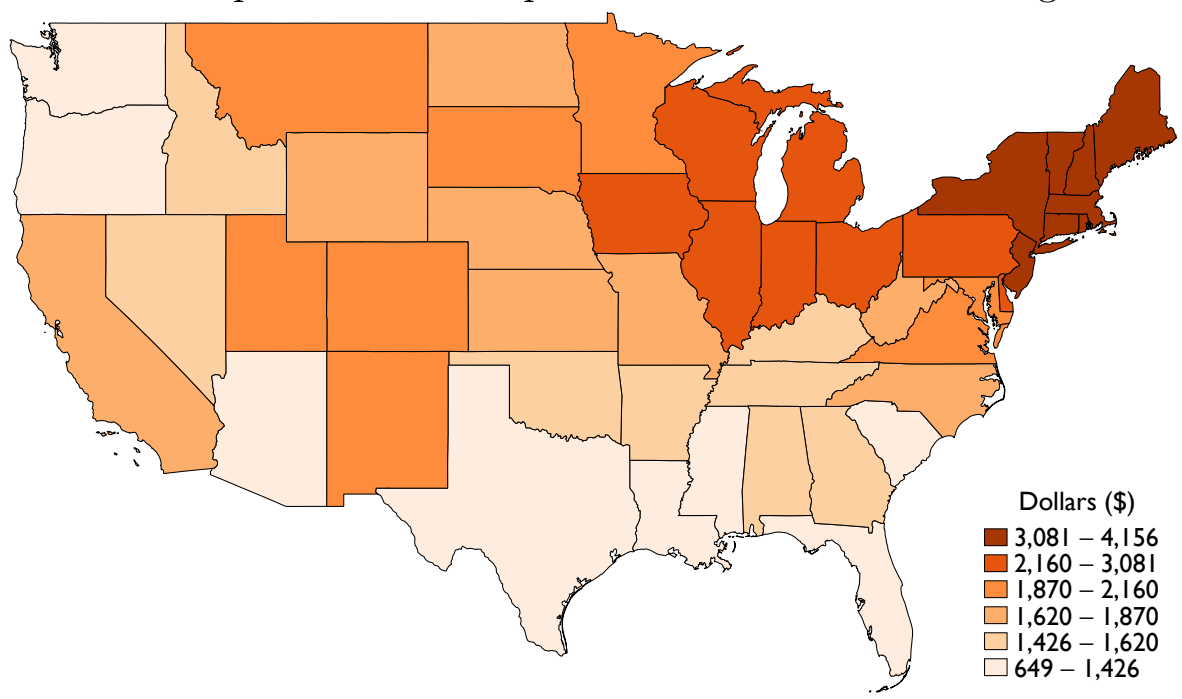


Appendix Table 1: Alternative Specifications for Electricity Price

\begin{tabular}{|c|c|c|c|c|}
\hline & $(1)$ & $(2)$ & $(3)$ & $(4)$ \\
\hline Current Price & $\begin{array}{c}-0.42^{* *} \\
(0.06)\end{array}$ & \multirow{3}{*}{$\begin{array}{c}-0.40^{* *} \\
(0.06)\end{array}$} & & $\begin{array}{c}-0.57^{*} \\
(0.21)\end{array}$ \\
\hline One Year Lag & & & & $\begin{array}{c}0.20 \\
(0.20)\end{array}$ \\
\hline One Year Lead & & & $\begin{array}{c}-0.42^{* *} \\
(0.06)\end{array}$ & $\begin{array}{l}-0.05 \\
(0.12)\end{array}$ \\
\hline Observations & $4,163,308$ & $4,163,308$ & $4,161,805$ & $4,161,805$ \\
\hline R-squared & 0.29 & 0.28 & 0.28 & 0.29 \\
\hline Cumulative Effect & $\begin{array}{c}-0.42^{* *} \\
(0.06) \\
\end{array}$ & $\begin{array}{c}-0.40^{* *} \\
(0.06) \\
\end{array}$ & $\begin{array}{c}-0.42^{* *} \\
(0.06) \\
\end{array}$ & $\begin{array}{c}-0.42^{* *} \\
(0.06) \\
\end{array}$ \\
\hline Other Energy Prices, Household Income & Yes & Yes & Yes & Yes \\
\hline HDDs, Housing Characteristics & Yes & Yes & Yes & Yes \\
\hline Year Fixed Effects & Yes & Yes & Yes & Yes \\
\hline Census Division Fixed Effects & Yes & Yes & Yes & Yes \\
\hline \multicolumn{5}{|c|}{$\begin{array}{l}\text { Note: This table reports coefficient estimates and standard errors from four separate least } \\
\text { squares regressions. Column (1) is the baseline specification, identical to the results in the } \\
\text { final column of Table } 2 \text {. Other specifications substitute a one-year lead or one-year lag or } \\
\text { both as indicated. All regressions are estimated using Census and ACS sampling weights. } \\
\text { Standard errors are clustered by state. }{ }^{* *} \text { Significant at the } 1 \% \text { level, }{ }^{*} \text { Significant at the } 5 \% \\
\text { level. }\end{array}$} \\
\hline
\end{tabular}


Appendix Table 2: Instrumental Variables Specification for Linear Probability Model

(4)

(5)

\section{OLS IV (Lags) IV (Lags) IV (Prices) IV (Both)}

\begin{tabular}{lccccc}
\hline & & & & & \\
Electricity Price, in logs & $-0.42^{* *}$ & $-0.39^{* *}$ & $-0.41^{* *}$ & $-0.42^{* *}$ & $-0.39^{* *}$ \\
& $(0.06)$ & $(0.06)$ & $(0.04)$ & $(0.03)$ & $(0.04)$ \\
Natural Gas Price, in logs & $0.21^{* *}$ & $0.25^{* *}$ & 0.09 & 0.02 & $0.14^{* *}$ \\
& $(0.07)$ & $(0.08)$ & $(0.06)$ & $(0.06)$ & $(0.05)$ \\
Heating Oil Price, in logs & 0.06 & 0.26 & $0.15^{* *}$ & $0.17^{* *}$ & $0.10^{* *}$ \\
& $(0.10)$ & $(0.23)$ & $(0.04)$ & $(0.02)$ & $(0.03)$ \\
& & & & & \\
Observations & $4,163,308$ & $4,163,308$ & $4,163,308$ & $4,163,308$ & $4,163,308$ \\
R-squared & 0.29 & 0.28 & 0.27 & 0.26 & 0.27 \\
\hline & & & & & No \\
Year Fixed Effects & Yes & Yes & No & Yes & Yes \\
Household Income & Yes & Yes & Yes & Yes & Yes \\
HDDs, Housing Characteristics & Yes & Yes & Yes & Yes & Yes \\
Census Division Fixed Effects & Yes & Yes & Yes & & \\
& & & &
\end{tabular}

Note: This table reports coefficient estimates and standard errors from five separate regressions. Column (1) is the baseline specification estimated using least squares, identical to the results in the final column of Table 2. The remaining columns instrument for residential electricity, natural gas, and heating oil prices. Columns (2) and (3) instrument using the one-year lag of residential prices. Column (4) instruments using crude oil prices, U.S. natural gas wholesale prices, and U.S. coal prices (bituminous, subbituminous, lignite, and anthracite). Column (5) uses both sets of instruments. All regressions are estimated using Census and ACS sampling weights. Standard errors are clustered by state. ${ }^{* *}$ Significant at the $1 \%$ level, ${ }^{*}$ Significant at the $5 \%$ level. 
Appendix Table 3: Willingness-to-Pay By State

\begin{tabular}{|c|c|}
\hline Florida & 85 \\
\hline Louisiana & 259 \\
\hline South Carolina & 346 \\
\hline Alabama & 346 \\
\hline Mississippi & 355 \\
\hline Georgia & 414 \\
\hline Texas & 435 \\
\hline Arizona & 486 \\
\hline North Carolina & 533 \\
\hline Tennessee & 586 \\
\hline Arkansas & 592 \\
\hline Kentucky & 670 \\
\hline Oklahoma & 688 \\
\hline West Virginia & 811 \\
\hline Virginia & 832 \\
\hline Nevada & 1,032 \\
\hline Oregon & 1,037 \\
\hline Missouri & 1,060 \\
\hline Maryland & 1,082 \\
\hline California & 1,102 \\
\hline Delaware & 1,126 \\
\hline Washington & 1,163 \\
\hline Kansas & 1,210 \\
\hline Nebraska & 1,561 \\
\hline New Mexico & 1,570 \\
\hline Iowa & 2,004 \\
\hline South Dakota & 2,085 \\
\hline Indiana & 2,092 \\
\hline North Dakota & 2,297 \\
\hline Idaho & 2,301 \\
\hline Ohio & 2,421 \\
\hline Pennsylvania & 2,662 \\
\hline Minnesota & 2,708 \\
\hline Colorado & 2,789 \\
\hline New Jersey & 2,799 \\
\hline Illinois & 2,845 \\
\hline Utah & 2,883 \\
\hline Rhode Island & 2,909 \\
\hline Wyoming & 3,093 \\
\hline Massachusetts & 3,125 \\
\hline Wisconsin & 3,137 \\
\hline Montana & 3,159 \\
\hline New York & 3,183 \\
\hline Michigan & 3,191 \\
\hline Connecticut & 3,347 \\
\hline Vermont & 4,081 \\
\hline Maine & 4,219 \\
\hline New Hampshire & 4,232 \\
\hline
\end{tabular}

